\title{
解説
}

\section{Concrete and Cryogenics (コンクリートと低温工学)}

\author{
F.H. TURNER
}

A Viewpoint Publication Cement and Concrete Association 1979

山 根昭

侏竹中工務店東京本店 東京都中央区銀座 8-21-1

（1983年 3 月22日受理）

\section{Sho YAMANE}

Takenaka Komuten Co., Ltd. 8-21-1. Ginza, Chuo-ku, Tokyo

(Received March 22, 1983)

\section{はじめに}

本書の解説に当って，はじめに依頼を受けたのは文 献紹介であったが,一読した結果, 極低温コンクリート の領域で広い範囲で丁寧にまとめた叢書がわが国では 見られないこと，各章を取上げるとそれぞれの分野の 専門家にとっては十分でないにしても他の分野につい ての概括的かつ基本的な知見を持つ意味で十分参考々 なること，また実務において管理面からも役立つこと などの点から, 全訳ではないが書の要点を整理して見 た。読者の興味をそそることができ，また設計者の手 元資料となればこの上ないと考える。

本書は，LNG (液化天然ガス) など極低温用貯蔵タ ンクに，プレストレストコンクリートを使用する場合 の基礎的な知識, 背景および概要について, 読みやす くまとめられたいわばコンクリート丵書である。簡明 な記述を旨として, 設計者に役立つよらに, 概論的に よく屯とめられて扣り，いわば指針をわかりやすく解 説したものと云えよう。

\section{序 章}

導入として液化ガスの効用を述べて扣り，扣もしろ い。ロンドン・キャナビィストリートで, 液化炭酸ガ スでプラスチックスの床にくっ付いたガムを剥がした こと，同様にカーペットの場合も液化窒素のスプレー でガムが剝がれること。医者の局部麻酔や止血に低温
を利用し，また死体の保存のための低温利用は周知で あること，極低温下で電気抵抗が失われることから， コンピューター設計者や送電線技師が極低温セルを検 討している（注：最近超LSI の開発では新素材に切り 換えられている) ことなどを挙げて，極低温領域の特 殊性を表現している。

全体の構成; 極低温の液体及びガスの特性から始ま り，低温～極低温の液体の貯蔵，設計上のコンクリー ト及びプレストレストコンクリート（以下 P C と記 す), 及び鋼材の極低温下の諸性質, 貯蔵タンクの実 施設計之仕様, 内外タンクの構造設計, その他の適 用，例えばパイプラインなどで結んでいる。巻末には 附録としてデザインデーターを載せて打り，諸単位の 換算表があるほか, 諸液化ガスの物理的性質, 液化温 度と压力, 安全性検討に必要な諸元等を提供してい る。度量衡を除く換算表と液化ガスの諸性質を附録と して末尾に Chart 6〜8,10～14に示した。これらの 諸章は著者の緒言にもあるように，ガイドラインある いはアウトラインを示すものではあるが，一応洩れな くカバーして拈り，幅広く読める書である。

\section{1 章}

極低温下の液体及びガスの性質を述べている。低温 技術は主として液体でガスを扱らことは周知である が，輸送及び貯蔵時に液体であれば，液化天然ガス (以下単に LNG と記す)の場合, 常温常圧下の容積の 


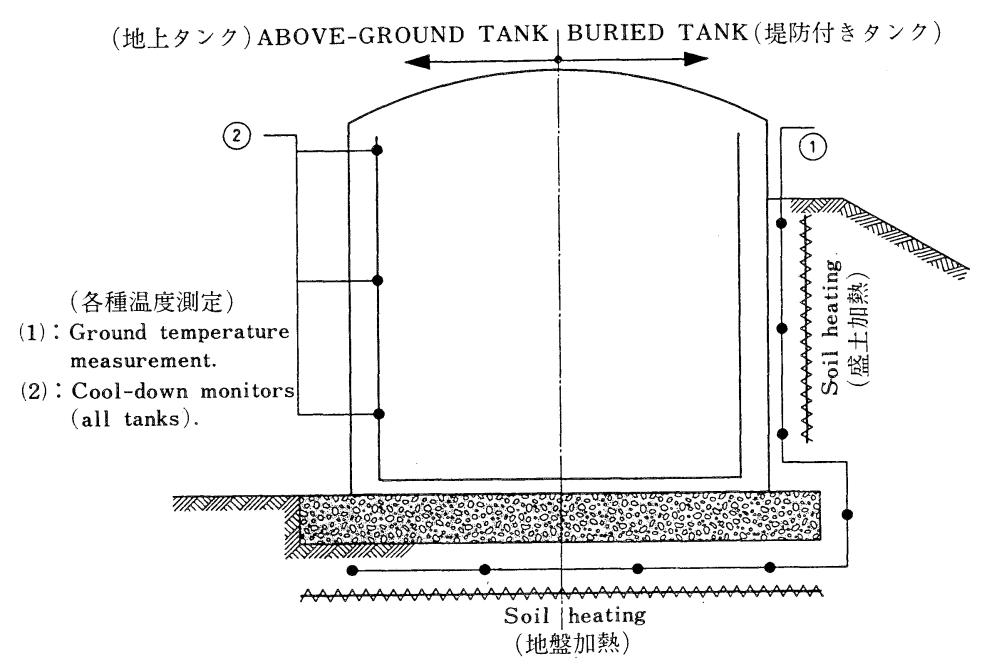

Figure 1.1(c) Thermal instrumentation。(温度調節設備)

約 $1 / 630$ であり，実用的かつ経済的であるからとして いる。この章では, 附録の物性表と対比して, ガスの 液体と臨界温度及び圧力と潜熱, 比重・比熱・熱容 量及び容積変化等, 物理的性質の概要を述べている (末尾の附録 Charts $6 \sim 14$ 参照)。LNG 及び LPG (ここでは天然または副産物としての液化石油ガス) の取扱い上の性質についても述べられている。例えば タンクの冷却に伴う地盤の凍結の保護, 蒸発または反 転現象とガス圧解放, 及び回収のためのレターンパイ プによる漏洩防止, タンクの内外温度差が $200^{\circ} \mathrm{C}$ に及 ぶ場合の構造体の動き，例光ば直径 $50 \mathrm{~m}$ のタンクの約 $100 \mathrm{~mm}$ 程度の収縮及びコンクリートの通常の立方体 強度の約 1.5 倍に及ぶ熱応力，等が提起されている。 液体ガスを 1 次しゃへいのみでコントロールするこ とは困難であるため，2次的な圧力解放バルブ等によ る設備上の配慮が必要であること, 荷重に対する考慮 及至は試験を必要とすること，等が $2 \sim 3$ の図を示し て述べられている(Fig. 1.1(c))。

タンクの安全性についてもこの章に述べられてい る。ただし実際の安全対策上の諸策についてではなく て，この章では主としてタンクからの液の大量の洩れ と火災について知られている10数件の事故の中で，代 表的な米国での 2 例が紹介されている。1つはオハイ オ州クリーブランドで1944年に起った鋼製タンクの大 事故で, 約 $5.5 \mathrm{~m}^{3}$ の LNG が漏洩したもので，火災に より第 2 のタンクも部分的崩壊を伴なった。漏洩した LNG は市の下水道に流入し，火災と爆発によって死 者 100 人，負傷者 300 人をこ光，10䇢所のプラントと
80戸の住宅， 200 台の自動車及び市の下水道システム が被桨し，その範囲は12へクタールをこえ，損害は当 時で約30億円にも上ったとしている。事故の原因は夕 ンクの設計の悪さ，延性の少ない金属の使用，適正な 事前調査検討の不足などの複合であったと説明してい る。今 1 つ事故は, 1973年 2 月10日に起こった二ュ 一ヨーク，ステートン島，テキサス・イースタン社の $\mathrm{PC}$ タンクの事故で, ナイロンーアルミニューム・コ ンポジットのフレキシブル・ライナー製で，ガス圧に よりメンブレンより次第にリークして断熱材に充満 し，ついには緩やかな爆発とフラシュオーバーを誘発 し，コンクリートの屋根ドームが破壊して約 40 人の作 業員が死亡したといら。このよらな事故の教訓から， 安全性について詳細な仕様が作られており，かつ二重 外殸を設けるなど二次の漏洩防止対策等，多くの厳密 な安全対策を考慮する必要があるとしている。この辺 はもしろ LNG 等貯蔵タンクの安全を計るための厳密 な設計と仕様を遵守すべき警告として，また低温液化 ガス取扱いの根本として強調されているものと思われ る。

\section{2 章}

極低温液体の貯蔵について, 設計概念図, メンブレ ン，断熱材及び荻害防止堤防の概要が図示して説明さ れている (Fig. 2.1 参照)。まず, 安全に関する基本 は，1）液の漏洩のないこと，2）液体に侵入する熱 を最小にすること，3）ガスに対して浸入または透過 の両方向に気密であること，であるとし，さらに4） 


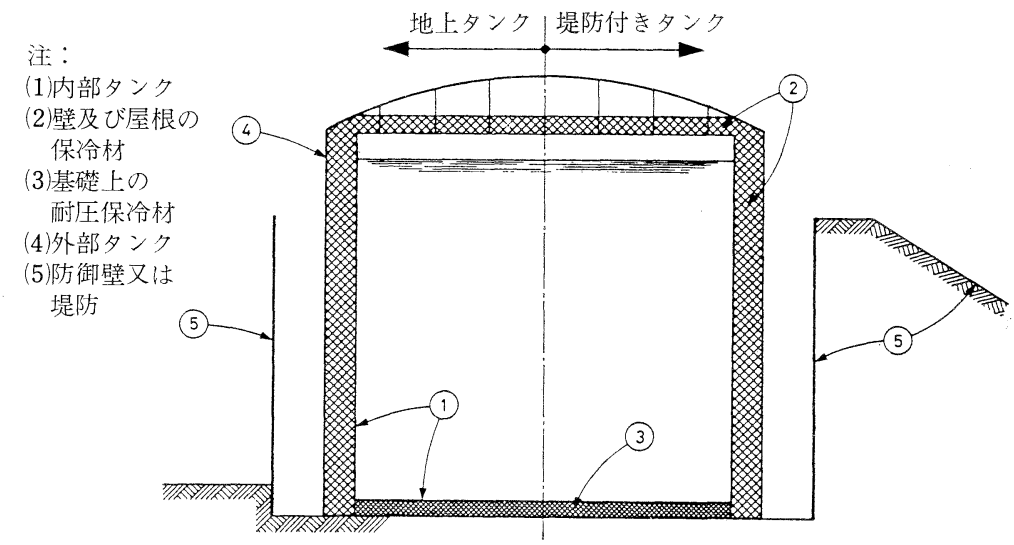

Fig. 2.1 Components of tank. (タンクの構成)

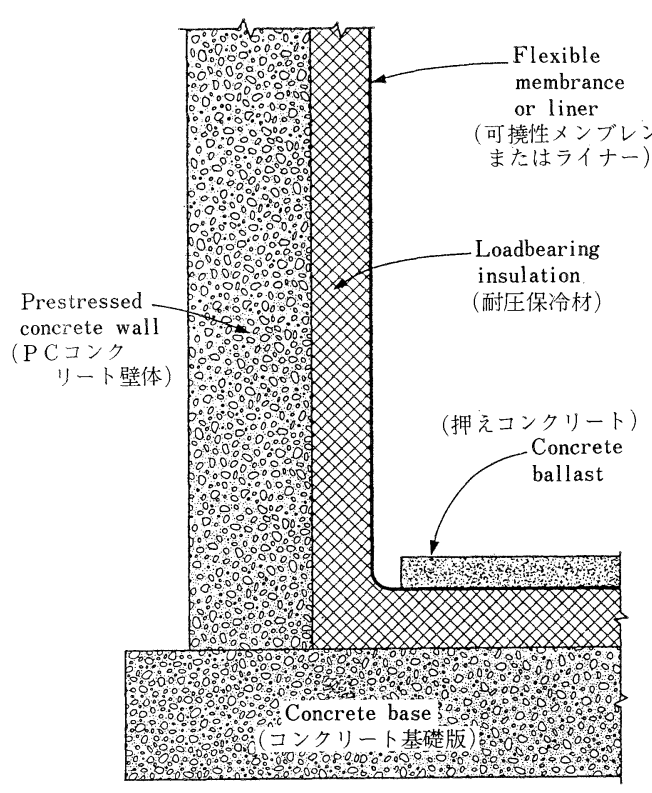

(b): Internal membrane:

Fig. 2.2 Membranes. (メンブレン)

いかなる理由であれ，破損または崩壞した場合，その 被害を最小にとどめることとしている。このことは一 次及び二次の安全性を考慮する必要性を示している。

極低温の液体を収納する内部タンクは，漏洩はもち ろ几，極くわずかに起る蒸発現象時のしみ出しなどが あってはならない。このため極低温下でぜい性となら ず，温度変化による伸縮に追随する材料で，かつ外部 タンク内で暴れることのない（変形の少ない）構造を 要求している。例えば金属性では高ニッケル鋼やアル

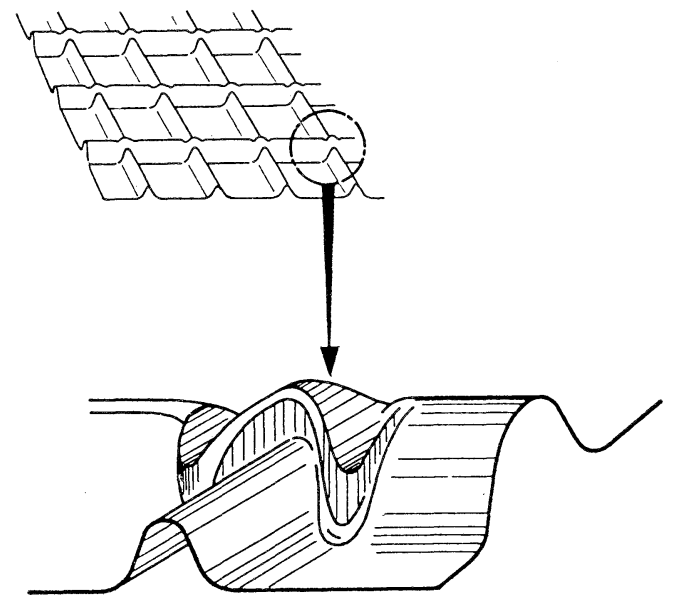

Fig. 2.3 Inherently flexible stainless steel membrane. （柔軟なステンレス製メンブレン）

ミニウム合金が経済的ではあるが万全ではないこと， P Cコンクリートでは極低温下の液体の浸透性のた め,ささにメンブレンを要することを説明し，図によ り P Cュンクリートに使用するメンブレンの設け方を 例示し，解説されている (Figs. $2.2 \& 2.3$ )。

断熱材（保冷材とも云う）の性能について，1）高い 遮熱効果と経済性，2)液体及びガスに対して不活性で あること，3)適用温度範囲に対して物理的に安定であ ること，4)引火性または爆発性液体の場合は非焰性で 

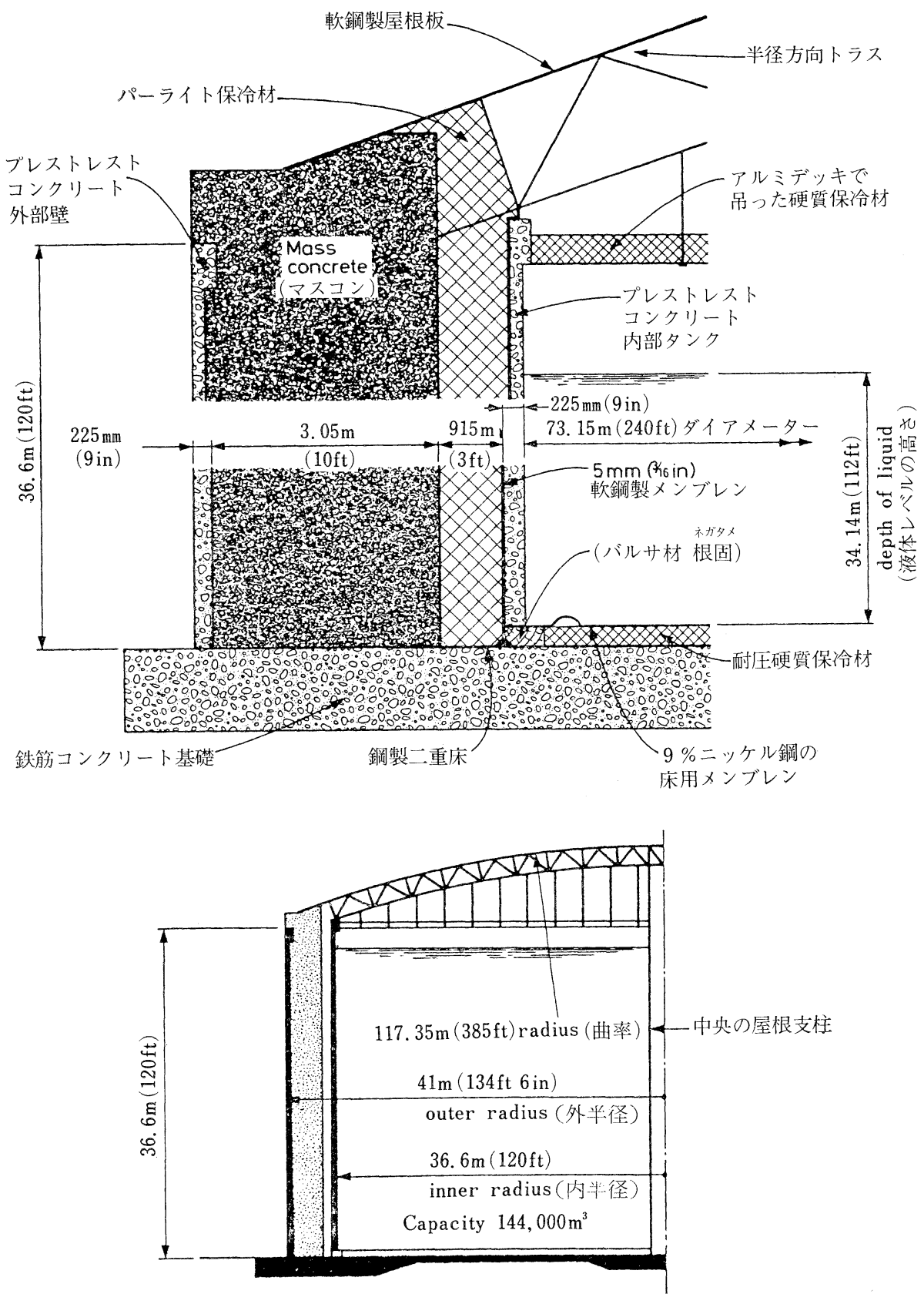

Fig. 2.9 LNG tanks at Staten Island, New York (Distrigas).

(ニューヨーク，ステートン島のデイストリガス社 LNG タンクの例) 
あることなどを基本としている。材料として粒状パー ライトを推奨し，その他発泡ガラスを取上げている が，説明にもあるよらにステートン島の事故からウレ タンフォームを忌避しているように思われる。ちなみ にわが国では, 硬質ウレタンフォーム, 発泡ガラス, 合 板及び塩化ビニールフォームなどが支圧保冷部分に， ロックウール及びグラスウール等が非支圧部に用いら れている。な找, 本書では保冷材の施工中に雨水や湿気 の透過による効果の半減を防ぐために, 内部タンクの 完成後に行ならことを推奖しているのは適切である。

外部タンクについては，軟鋼製タンクを推奖してい る。一般に金属性タンクでは完成よりも施工中に弱点 があり，突風時に被害を受けやすい。チェスシャイア

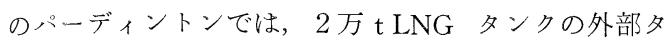
ンクの工事中に1973年 2 月の暴風時に崩壊したとい う。その点コンクリートタンクはその心配がなく，さ らにきれつを防止するためプレストレス構造とすべき だとしている。

安全堤防または防御壁については, 主として液化が スの漏洩による二次荻害としての流出及び火災を封じ 込める目的のもので, 万が一の事故の拡大を防止す る。壁体は 1 回限りで解体されるがそれで十分であ り,さらにP Cとすることが望ましいとしている。特 そアンモニア及び塩素など毒性のある危険物に対して は取扱い上の制限と封じ込めを対策としているが，そ れ以上の策については触れていない。

その他 LNG 貯蔵タンクの開発の歴史について, 初 期には金属製タンクに関連する溶接技術の改良，次い で出現したP C 貯蔵タンクの開発等が述べられてい る。この章の終りには世界各国のタンクの実施設計の 5 例が図解されて扣り，それぞれのデザインが異なっ ていて與味深い。特にステートン島ディストリガス社 のツィンタンクは容量 $144,000 \mathrm{~m}^{3}$ ，世界最大 (1979年) で, 市の委員会の要請で「最大の安全性」を基本とし て建設された（Fig. 2.9 参照）。

\section{章}

$\mathrm{pC}$ （プレストレストコンクリート）構造のコンク リート及び P C 鋼材の極低温下の性質について述べら れている。極低温下で要求される延性はコンクリート 自身は持っていないので，高い引張強度を持つ高炭素 鋼の P C 鋼棒または P C 鋼線との複合で P C 構造物が 成り立つ。

設計原理として，溶接を伴なら金属性タンクまたは
ライナーの延性の必要性について, 金属の溶接部の応 力解除後に負担すべき引張応力に耐えるためには十分 な延性が必要であること，シャルピーの衝撃試験時に 見られるようなぜい性的破壊をなくすためにも延性が 必要であるとしている。この点 P C 構造では温度に拘 わらずイニシャル・プレストレス応力がその後の引張 応力を上回るのでュンクリートに引張応力を生ずるこ とはなく，またプレストレス鋼線が多数のより線から 成っているので, 成長するきれつ等の損傷を起こす危 険がなく，極低温タンクとして貯蔵すべき液の種類を 問わず最適であるとしている。しかし，実際のタンク としては主として金属性メンブレンを用いて，保冷材 あるいは躳体のコンクリートへの液の浸入を阻止し， 二重・三重の安全を考慮する姿勢からは，金属製メン ブレンは絶対に必要であり，著者の P C 製タンクの強 調はややオーバーにも思觉る。

コンクリートについて，P Cタンクの材料となるコ ンクリートの物理的性質については, アメリカン・ガ 不協会 (AGA), B.E. Eakin らの 1963 年の地下タン クの報告にある、アメリカ・ポートランド・セメント 協会 (PCA), G.E. Monfore らの実験報告によるデー タをそのまま引用している。コンクリートの圧縮強 度, 引張強度, 弾性係数, ポアソン比, 低温収縮, な ぞであり，他の文献の例または対比については考慮さ れていない。もともと G.E. Monfore らの実験報告 は，それ以前の吉田，Saemon J.C.らに次いで古い が，広範囲に亘って現在も支持されているもので， Monfore 以後の Moskvin ら, Tognon, Wischers ら, 小谷ら, Radjy, Marechál, Litvan ほかの報告は上記 Monfore らの報告を補足するものであり，多少のデー ターの狂いは止むを得ないとしても，1960年代以後の 研究の基本的なものとして周知になっている。欲を云 えばもう少し上記の報告とも合わせて傾向的に示すべ きではなかったかとも思われる。

コンクリートの極低温下の強度性状について G.E. Monforeの結果を要約すると，圧締強度は極低温下で

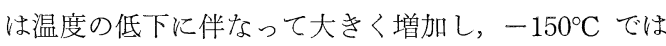
常温時の約 $3 \sim 5$ 倍に達し, 富調合よりも貧調合の方 がその増加率が大きい。引張強度も極低温下で増加 し，-60兄で極大に達するが，圧縮強度よりも倍率は やや小さく常温時の約 2.5 倍程度にとどまる。これら の性質はコンクリート中の自由水の凍結に関係してい るもので, 湿潤・気乾及び絶乾の供試体を比較する と，湿潤供試体は常温時の約 $240 \%$ も増加するが，50 

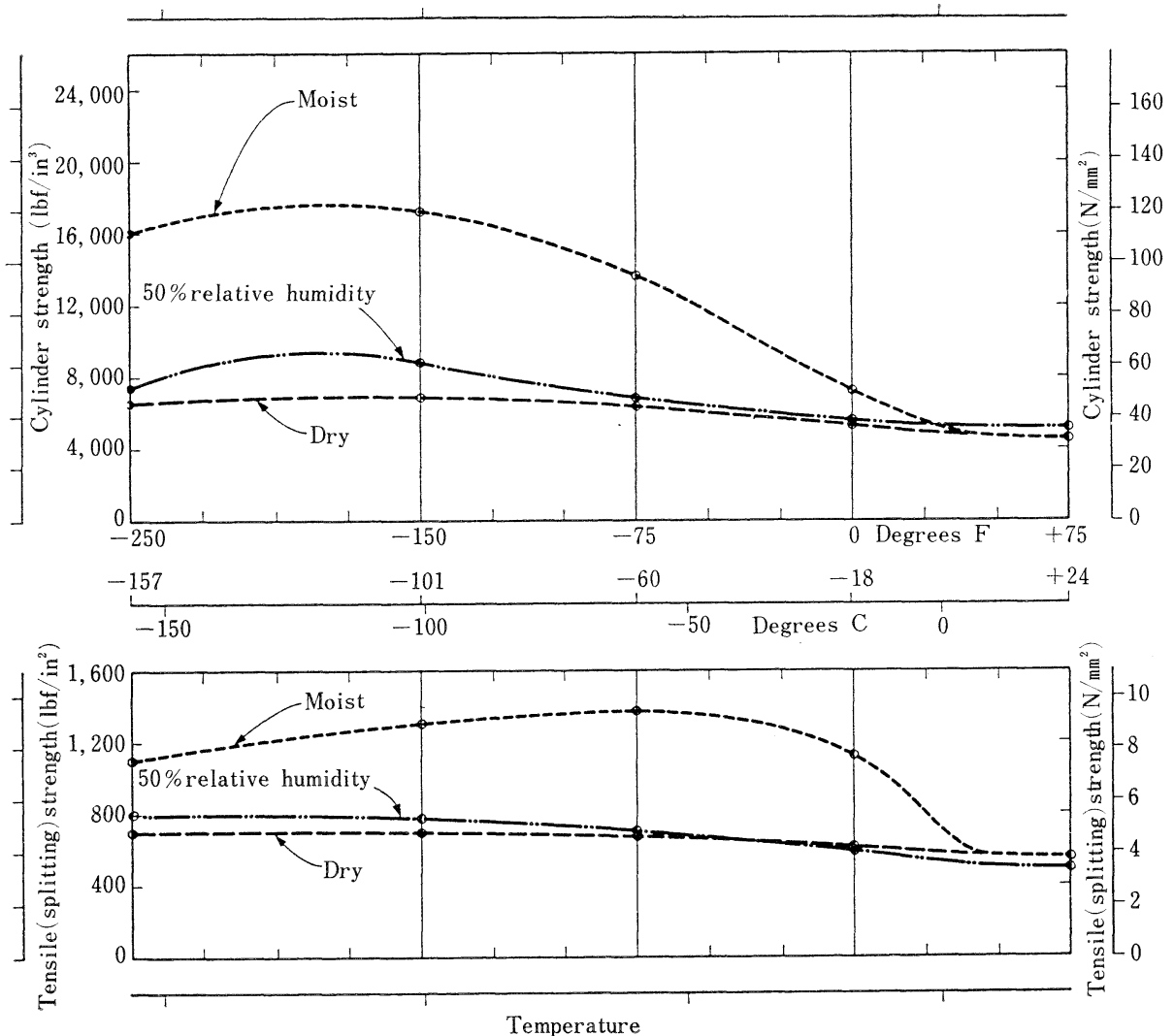

Fig. 3.2 Effect of moisture content on strength of concrete (Mix 2 at various temperatures) (コンクリートの強度に及ぼす含有水分の影響, Monfore \& Lentz の文献)

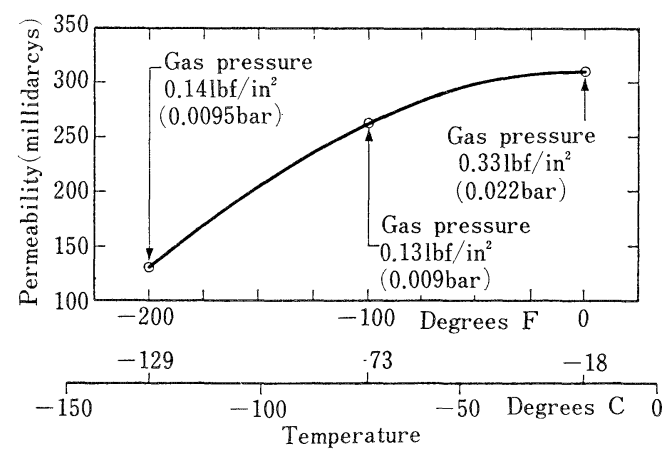

Fig. 3.5 Permeability to methane of oven-dried concrete. (絶乾コンクリートの場合の メタンの透気性)

\% RH の養生による気乾状態では約 $8 \%$, 絶乾状態で は汪とんど増加しない（Fig. 3.2）。ポアソン比は温度 に㟫とんど影響されない。
長さ変化については, 軽量コンクリートではー $18^{\circ} \mathrm{C}$

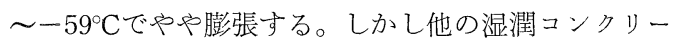
トでは，ほとんど変化がない。熱膨張率は，24〜一 $157^{\circ} \mathrm{C}$ の範囲で $6.6 \times 10^{-6} /{ }^{\circ} \mathrm{C}$ 程度であるが，軽量コン クリートでは $8.1 \times 10^{-6}$ 前後である。熱伝導率は常温

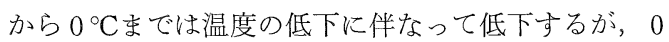
${ }^{\circ} \mathrm{C}$ で転して 1 たん大きくなり，さらに温度の低下に 伴なって増加する。

透気性については, 米国ガス工学研究所の実験結果 が示されて括り，湿潤状態の供試体ではメタンガスは 浸透しないが，50\% RH で養生した気乾状態では，一 $73{ }^{\circ} \mathrm{C}$ で常温の約 $38 \%,-130{ }^{\circ} \mathrm{C}$ で約 $67 \%$ であり, 温度 が低下すると透気性が増加する。また絶乾状態では低 温で減少するとしている(Fig. 3.5)。

な拉，コンクリートの物性に関する上記のデータは 基礎的な知見としては満足しているが，設計にとって は十分とは云光ないので，担当者はもら少し幅広く文 献を見て执く必要があると考えられる（解説者注）。

低温工学 
Table 3.5 プレストレス・ワイヤーの極低温下の性質

\begin{tabular}{|c|c|c|}
\hline 項 & 目 & 性 \\
\hline 引 張 強 & 度 & $\begin{array}{l}+20^{\circ} \mathrm{C} \text { 対してー } 196^{\circ} \mathrm{C} \text { で約 } 8 \% \text { 増加する。 } \\
25 \% \text { な゙増加するといらレポートもある。 }\end{array}$ \\
\hline 断面減少(絞 & & $+20^{\circ} \mathrm{C} て ゙ 30 \sim 40 \%$ 対して, $-196^{\circ} \mathrm{C}$ では23〜 33\% \\
\hline 伸 & び & -196ㄷ25〜 50\%に減少 \\
\hline 弾 性 係 & 数 & $+20^{\circ} \mathrm{C}$ に対してー $196^{\circ} \mathrm{C} て ゙ は$ 約 $6 \%$ 増加 \\
\hline 収縮 & 率 & $\begin{array}{l}+20^{\circ} \mathrm{C} \sim-100^{\circ} \mathrm{C} \text { で } 11 \times 10^{-6} /{ }^{\circ} \mathrm{C} \\
+20^{\circ} \mathrm{C} \sim-196^{\circ} \mathrm{C} \text { あ゙ } 10.3 \times 10^{-6} /{ }^{\circ} \mathrm{C}\end{array}$ \\
\hline シャルピー & & $+20^{\circ} \mathrm{C}$ 対してー $196^{\circ} \mathrm{C} て ゙$ 約 $60 \%$ 減少 \\
\hline
\end{tabular}

Table 3.6 プレストレス鋼棒（マッカロイ社）の極低温下の性質

\begin{tabular}{|c|c|}
\hline 項 & 性 \\
\hline 引 張 強 度 & $+20^{\circ} \mathrm{C}$ 対して,$-196^{\circ} \mathrm{C}$ で約 $16 \%$ 以上増加する。 \\
\hline 断面及び伸び & ばらつく，塑性破壊やぜい性破壊が見られる。 \\
\hline 弾 性 係 数 & $+20^{\circ} \mathrm{C}$ に対して，-196Cでわずかに増加する。 \\
\hline 収縮率 & $+20^{\circ} \mathrm{C} \sim-100^{\circ} \mathrm{C}$ で $11 \times 10^{-6} /{ }^{\circ} \mathrm{C}$ \\
\hline シャルピー值 & 極低温下で小さい \\
\hline
\end{tabular}

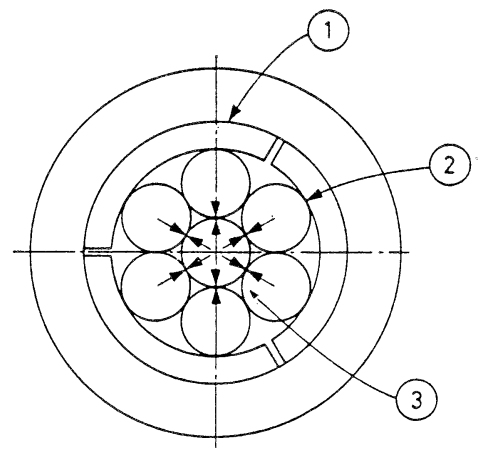

(a)

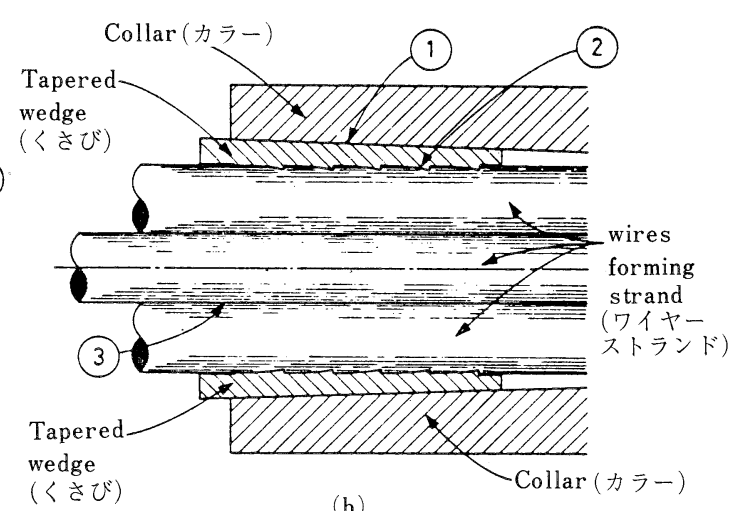

(b)

Fig. 3.6 Schematic diagram of anchor for 7-wire strand.（7 本より線のアンカー部分 (くさび方式))

\section{PC鋼材について;}

いくつかの例外はあっても，全般にはほぼデータは 揃っているとしている。

P C 鋼線（ワイヤ一）及び P C 鋼棒について標準的 な值について表示している（Table 3.5 及び3.6)。P C ワイヤーの引張強度については, わが国の場合よりも ややシビヤになっている。

PC鋼より線については, センターワイヤーと円周 ワイヤーが配置される 7 本より線の一般的な図示がな
されくさびに鋸状の歯どめをかけたくさび型アンカ 一を示している。またこれの荷重一歪曲線を示し，+ $20^{\circ} \mathrm{C}$ と比較し $-196^{\circ} \mathrm{C}$ で引張強度が大きく増加し, 弾 性係数もわずかに増加することを示している (Figs. 3. $6 \sim 3.7$ 参照)。

な和，金属の薄層剥離（いわゆるラミネーション）, 溶接時のきず，含有物及び気泡について触れ，これら の欠陷がいわばノッチ効果となるとして警告してい る。 


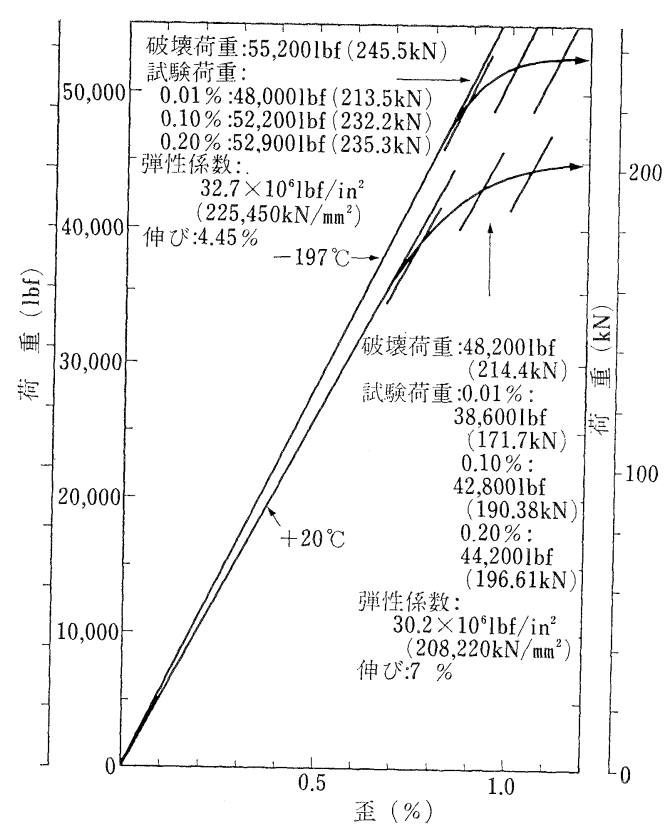

Fig. 3. 7 Load-strain curves for Briden 'Dyform' $13 \mathrm{~mm}$ drawn 7-wire strand. ( 7 本上 り線に引いたブリドンの $13 \mathrm{~mm}$ 異形筋 の荷重一歪曲線)

プレストレスのシステムについて，1)鋼線，鋼棒ま たは引抜さストランドで構成されるテンドンは，通常 のより線を優先すべきであること，2）単線，鋼棒また は引抜きより線は，複数鋼線などが与えられるテンド ンでは，複数ワイヤーを優先すること，3)直接アンカ 一方法が採用される場合は，〈さび型アンカーを優先 することなどの点を強調している。しかしこの項では 通常用いられる工法の仕様まで揭載寸べきであったと 思われる。

\section{4 章}

実施設計について述べられている。通常は設計施工 で, 最適かつ経済的な設計が要求される。一般の構造 物の場合よりも厄介で，慣れないことが多く，次章の 構造設計と分離して此処に載せている。

設計仕様について示されている項目をなとめると表 1 のようになる(解説者注)。

な特，一般に設計仕様の適正でないものが多く，こ のためにも巻末に附録を添付したとしている。

主要寸法の説明では，設計者が保冷材の表面積が最 小となるタンクの規模は, 必要貯蔵量 $V か ゙$ 示されれ ば, 半径は $r=(V / 2 \pi)^{1 / 3}$, 高さは $n=V / \pi r^{2}=2 r$ で求 められるとしている。

保冷材についても，仮定した保椧材の必要厚さを， 内外温度差及び保冷材の熱伝導率から，単位面積あた りの熱負荷を計算して求める方法を説明している。

以下に保冷材の熱負荷の計算例を示す。

[保冷材の熱負荷の計算例]

1）通常の貯蔵タンクで，1日あたりの蒸発損失 (ボイルオフ) は0.04\%と仮定,

$$
\begin{aligned}
0.04 \times 10^{-2} \times 20,000 & =8 \text { (英) ton } / \text { day } \\
& =8.131 \text { tonnes } / \text { day }
\end{aligned}
$$

LNG の蒸発潜熱は $488 \mathrm{~kJ} / \mathrm{kg}$ で与兄られるので， 許容熱取得は

$$
8.131 \times 1,000 \times 488=3,968,000 \mathrm{~kJ} / \text { day }
$$

2) 基礎に対して

Fig. 4.2 の断面寸法から 泡ガラスの厚さ：0.65m 温度降下 : $165+25=190 \mathrm{~K}$

\begin{tabular}{|c|c|}
\hline 項 & 仕 \\
\hline 種類及び容量 & 液化メタンまたは LNG 20,000 t \\
\hline 設 計 項 目 & 内・外タンク, 保冷, 配管及びバルブ設備 \\
\hline ボイル・オフ & 0.04\%/日をこえない \\
\hline 容積 & 45,000色をこ光ない \\
\hline 液面の高さ & タンク上端より $0.5 \mathrm{~m}$ 以下 \\
\hline 試験の遂行 & 外タンクのガス压カテスト \\
\hline 液 体 の温度 & $-165^{\circ} \mathrm{C}$ ，ただし外部温度は $+25^{\circ} \mathrm{C}$ と仮定 \\
\hline 液体の比重 & $0.5 \mathrm{~kg} / \mathrm{l}$ \\
\hline 液 体 の潜 熱 & $448 \mathrm{~kJ} / \mathrm{kg}(210 \mathrm{Btu} / \mathrm{lb})$ \\
\hline タンクの压力 & 外タンクの最大内圧 $140 \mathrm{mbar}$, 最大真空度 $10 \mathrm{mbar}$ \\
\hline
\end{tabular}
熱伝導率 : $0.145 \mathrm{~kJ} / \mathrm{mKh}$

表 14.1 節 Design specification（設計仕様） 


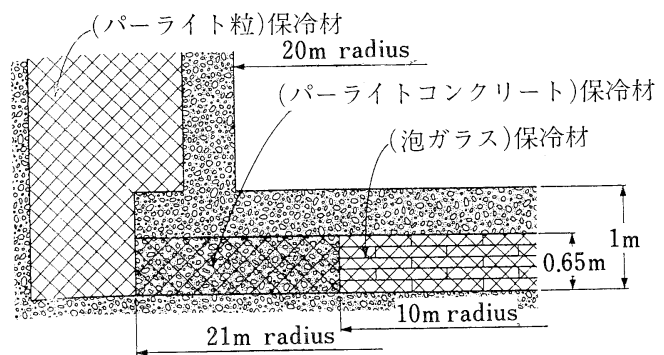

Fig. 4.2 Sketch of insulation below wall of inner tank. (内タンク下部の断面)

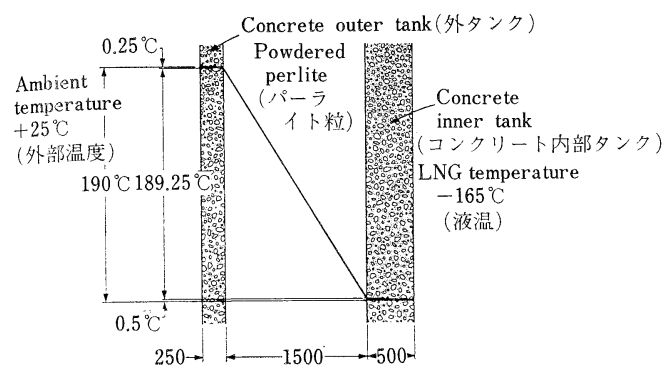

Fig. 4. 4 Temperature gradient through tank wall. (タンクの壁体を通 じての温度勾配)

従って熱取得は

$$
\begin{aligned}
& 0.145 \times \pi \times 19^{2} \times \frac{1}{0.65} \times 190 \times 24 \\
& =1,154,000 \mathrm{~kJ} / \text { day }
\end{aligned}
$$$$
\text { パーライトコンクリート：厚さ } 0.65 \mathrm{~m}
$$

\section{熱伝導率 : $0.34 \mathrm{~kJ} / \mathrm{mKh}$}

従って熱取得は

$$
\begin{aligned}
& 0.34 \times \pi \times\left(21^{2}-19^{2}\right) \times \frac{1}{0.65} \times 190 \times 24 \\
& =600,000 \mathrm{~kJ} / \text { day }
\end{aligned}
$$

從って基礎を通過する全熱取得は

$1,154,000+600,000=1,754,000 \mathrm{~kJ} /$ day 壁及び屋根を通じて許容される熱取得は

$$
3,968,000-1,754,000=2,214,000 \mathrm{~kJ} / \text { day }
$$
壁と屋根の合計面積は

$$
\begin{aligned}
& \pi \times 20^{2}=1,257 \mathrm{~m}^{2} \\
& 2 \pi \times 20 \times 40=5,027 \mathrm{~m}^{2} \\
& \text { 計 } \quad \frac{6,284 \mathrm{~m}^{2}}{}
\end{aligned}
$$

$1 \mathrm{~m}^{2}$ あたりの熱取得は

$$
\frac{2,214,000}{6,284}=353 \mathrm{~kJ} / \mathrm{m}^{2} \cdot \text { day }
$$

3）パーライト粒の部分

パーライト粒の熱伝導率は $0.1 \mathrm{~kJ} / \mathrm{mKh}$ であるか b,

$$
\begin{aligned}
& \frac{0.1}{t} \times 190 \times 24=353 \\
& \therefore \quad t=1.292 \mathrm{~m}
\end{aligned}
$$

通常は安全を見て壁の保冷材の厚さは $1.5 \mathrm{~m}$ (パー ライト粒）とする。

4）外タンク・保冷材・内タンクの合計

$\frac{1}{k_{1}}+\frac{1}{k_{2}}+\frac{1}{k_{3}}+\cdots=\frac{1}{k} よ り$

$\left(\frac{0.25}{12.5}+\frac{1.5}{0.1}+\frac{0.5}{12.5}\right)^{-1} \times 190 \times 24=302.8 \mathrm{~kJ} / \mathrm{m}^{2} /$ day

コンクリート壁体の効果を 0 とすれば，パーライト 粒の保冷層では

$\frac{0.1}{1.5} \times 190 \times 24=304 \mathrm{~kJ} / \mathrm{m}^{2} /$ day

従って各構成材を通過する温度変化は

外壁では, $12.5 \times \frac{1}{0.25} \times 24 \times T_{1}=302.8$ より

$$
T_{1}=0.25^{\circ}
$$

パーライト粒の保冷層では

$$
0.1 \times \frac{1}{1.5} \times 24 \times T_{2}=302.8 \text { より }
$$

$$
T_{2}=189.25^{\circ}
$$

内壁では $12.5 \times \frac{1}{0.5} \times 24 \times T_{3}=302.8$ より

$$
T_{3}=0.50^{\circ}
$$

全温度変化は

$$
189.25+0.50+0.25=190^{\circ}
$$

となる。

外周防護壁についても, 漏洩を考慮した主タンクと の間隔及び高さを提示し，これらの漏洩が液体の満た 
ん時に起こることが多いことから，計算以上とすべき だとしている。

基礎については，地下水の処理及び凍結防止につい てやや簡弾に説明して拉り，ヒート・パイプまたは空 隙による対策に触れてはいるが，物足りない点が見ら れる。

タンクの荷重分布は液体とタンク軀体及び保冷材を 加光て, 高さ $40 \mathrm{~m}$ で重量約 $20 \mathrm{t} / \mathrm{m}^{2}$ と考光られ, 压力 テストは $26 \mathrm{t} / \mathrm{m}^{2}$ とすべきだとしている。もちろんタ ンク壁体の基礎はさらに増加し，コンクリートの厚さ $0.5 \mathrm{~m}$ で壁体の重量は $1 \mathrm{~m}$ あた， $48 \mathrm{t} / \mathrm{m}$, 厚さ 0.25 $\mathrm{m}$ の場合は $35 \mathrm{t} / \mathrm{m}$ を見るべきだとしている。この液 体圧力及び重量の分布をいくらかでも差を縮めるため
に版としての曲げ及び地耐力の影響を考慮して内部タ ンクの厚さを $2 \mathrm{~m}$ にする必要があるという。その他, 火災時の焰の温度は $1,350^{\circ} \mathrm{C}$ で, 火陥からの距離と空 気温度が表示されている。

実施すべき試験では，液に対する漏洩検査としての 湛水試験，空気圧試験を必要としている。水の場合は 設計荷重の 1.25 倍, ガスまたは空気圧の場合は 1.2 倍 の值を採用することなどとしている。

\section{5 章}

タンクの構造設計について述べられているが，経験 ある設計者にとっては大して困難なものではないとし ている。

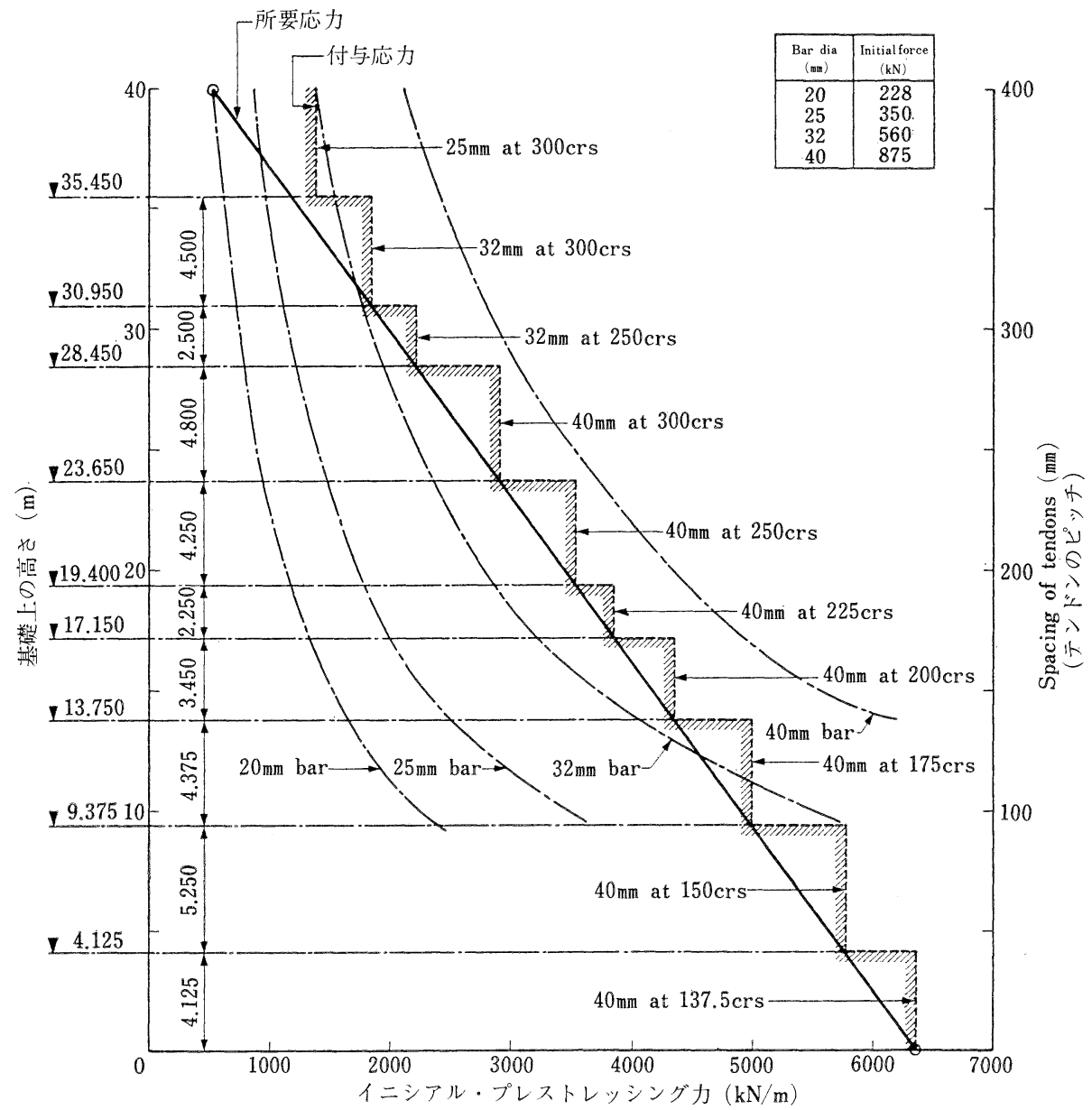

Fig. 5.3 Determination of pitch of tendons. (プレストレス・テンドンのピッチ計算図表) 注: $\mathrm{crs}$; ピッチ（間隔） 


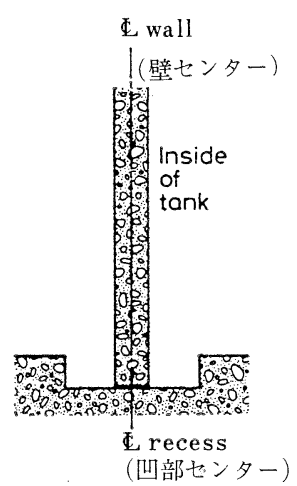

(a) プレストレス導入前

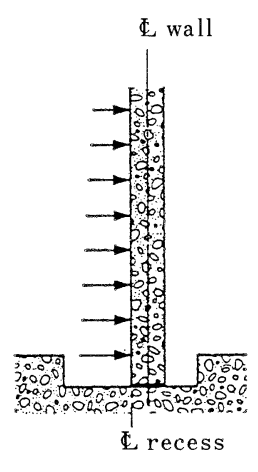

（b）導入時の移動

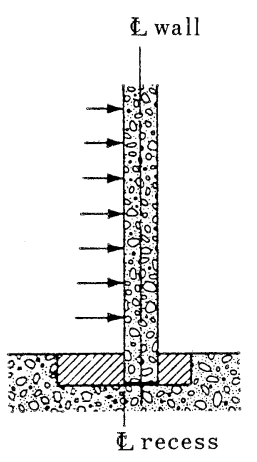

(c) 導大後のピン支持

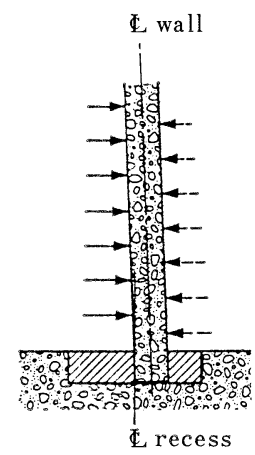

（d）タンク使用後のピン 支持壁体の荷重による 自由回転

Fig. 5.4 Movement sequence at bottom of tank wall. (タンク下部の動きと支持の過程)

Table 5.1 円筒及び底盤に拈忷る変形と応力の求め方
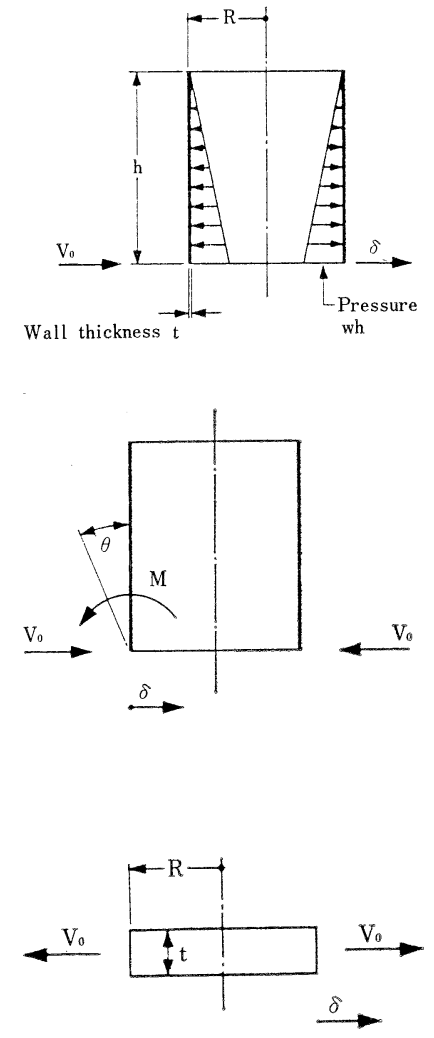

円筒容器内の比重 $w の$ 液体の圧力の影響 ;

無拘束壁底部に打ける半径方向の移動は,

$$
E \delta=w h \frac{R^{2}}{t}
$$

ピン状態壁底部の反力は, 単位長さにつき

$$
V_{0}=2 D \lambda^{3} \cdot w h \frac{R^{2}}{t}
$$

円筒底部の単位長さあたり半径方向反力 $V_{0}$ の影響; 底部の半径方向の移動は,

$$
E \delta=\frac{V_{0}}{2 D \lambda^{3}}
$$

底部での傾斜角は，

$$
E \theta=\frac{V_{0}}{2 D \lambda^{3}}=\lambda \times E \delta
$$

最大曲げモーメント $=0.3225 \frac{V_{0}}{\lambda}$

……底盤の上 $\frac{\pi}{4 \lambda}$ の高さに掠いて

底盤の縁に扣ける半径方向反力 $V_{0}$ の影響;

半径方向の移動は，

$$
E \delta=\frac{R V_{0}}{t}(1-\nu)
$$

$$
\begin{aligned}
& \text { 注; } D=\frac{t^{3}}{12\left(1-\nu^{2}\right)}, \quad \lambda=\left(\frac{3\left(1-\nu^{2}\right)}{R^{2} t^{2}}\right)^{1 / 4} \text {, } \\
& \nu \text { : ポアソン比, } E \text { : 弾性係数 }
\end{aligned}
$$


Table 5.2 鉛直方向 P C 鋼材

\begin{tabular}{|c|c|c|c|c|c|}
\hline 底盤からの高さ（m） & 0 & 10 & 20 & 30 & 40 \\
\hline 設計用曲げモーメント $(\mathrm{kNm} / \mathrm{m})$ & $\begin{array}{c}186 \\
\text { (基礎の拘束) }\end{array}$ & (合 ${ }^{111}$ 成 力) & (温度応力) & 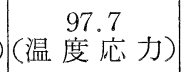 & (温度応力) \\
\hline 曲げ応力度 $\left(\mathrm{N} / \mathrm{mm}^{2}\right)$ & 4.46 & 2.66 & 2.34 & 2.34 & 2.34 \\
\hline 所要合圧縮力度 $\left(\mathrm{N} / \mathrm{mm}^{2}\right)$ & 0.7 & 0.7 & 0.7 & 0.7 & 0.7 \\
\hline 全応力度 $\left(\mathrm{N} / \mathrm{mm}^{2}\right)$ & 5.16 & 3.36 & 3.04 & 3.04 & 3.04 \\
\hline 死（固定）荷重 (N/mm²) & 0.96 & 0.72 & 0.48 & 0.24 & 0 \\
\hline 所要残留プレストレスカ度 $\left(\mathrm{N} / \mathrm{mm}^{2}\right)$ & 4.20 & 2.64 & 2.56 & 2.80 & 3.04 \\
\hline 摩擦ロスー $3 \% / 10 \mathrm{~m}$ & 0.50 & 0.38 & 0.25 & 0.13 & 0 \\
\hline 損失前のプレストレス力度 (N/mm²) & 4.70 & 3.02 & 2.81 & 2.93 & 3.04 \\
\hline 損失前の実プレストレスカ度 $\left(\mathrm{N} / \mathrm{mm}^{2}\right)$ & 4.70 & & & & 4.70 \\
\hline その他の損失 (N/mm²) (11.93\%) & 0.50 & & & & 0.50 \\
\hline イニシャルプレストレス $\left(\mathrm{N} / \mathrm{mm}^{2}\right)$ & 5.20 & & & & 5.20 \\
\hline イニシャルプレストレスカ $(\mathrm{kN})$ & \multicolumn{5}{|c|}{$5.2 \times \frac{1,000}{1,000} \times 500=2,600 \mathrm{kN} / \mathrm{m}$} \\
\hline $\begin{array}{l}40 \mathrm{mmbar} \text { に拈けるイニャシルプレス } \\
\text { トレッシング }\end{array}$ & \multicolumn{5}{|c|}{$875 \mathrm{kN} / \mathrm{m}$} \\
\hline ダブル配筋のピッチ & \multicolumn{5}{|c|}{$2 \times 875 / 2,600=0.675 \mathrm{~m}$} \\
\hline ジングル配筋のピッチ & \multicolumn{5}{|c|}{$0.338 \mathrm{~m}$} \\
\hline
\end{tabular}

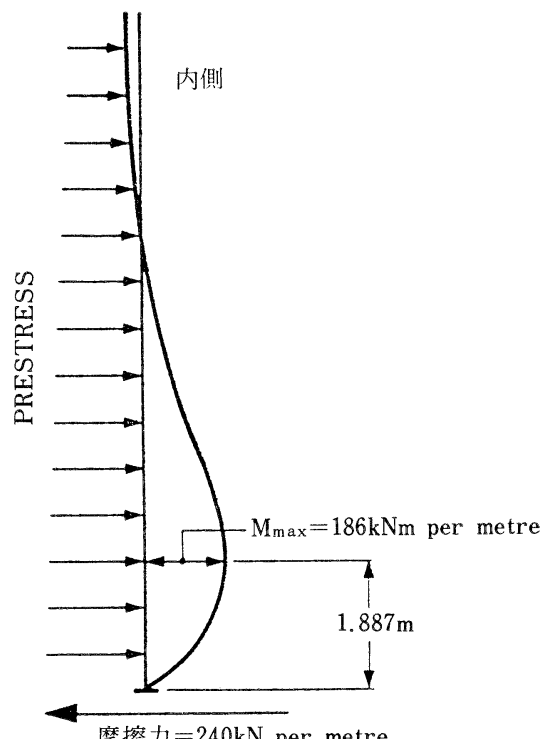

摩擦力 $=240 \mathrm{kN}$ per metre

Fig. 5.5 Moment at base of wall (pretress only). （壁下部の曲げモーメント，プレストレスの 久の場合）

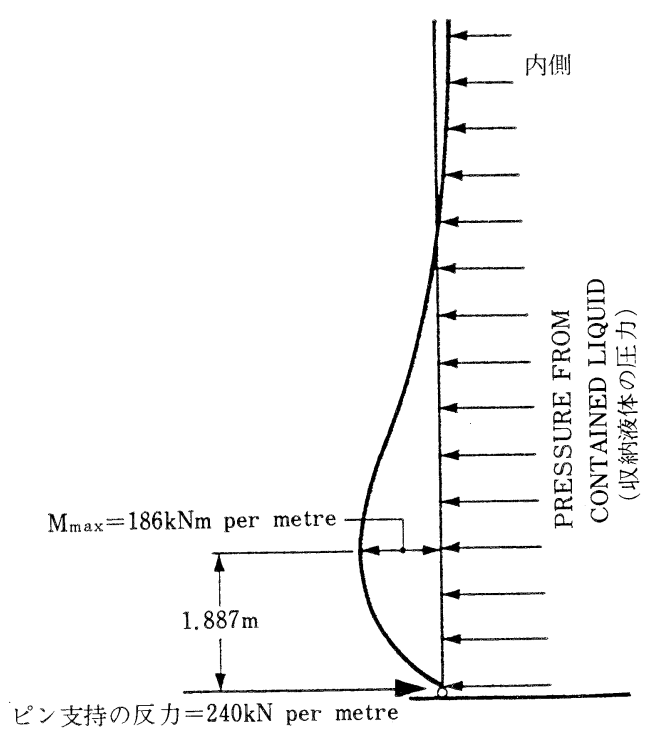

Fig. 5.6 Moment at base of wall (fluid pressure only).(壁下部の曲げモーメント，液圧 のみの場合) 
設計の基本について，極低温用コンクリート・タン クの規準は特にはないが，C P 110 及びB S 5337の規 格があり，鋼製タンクには， $-50^{\circ} \mathrm{C}$ までのB S 4741 と ー1970 までのB S 5387の規格が参考となるとしてい る。

内部タンク；

円周方向の引張力は, 液の比重と高さと半径の積で 求められ，壁の最小合圧縮力は最小合成圧縮応力度之 壁厚との積で求められ, 壁の最下部のプレストレス損 失後の主縮応力は上の 2 つ和となる。初期プレスト レスカはコンクリートの強度特性值と弾性係数を仮定 し，銅より線の場合またはポストテンション鋼棒の場 合の損失を計算する。同様に鋼より線及びポストテン ション鋼棒の初期プレストレスカと $\mathrm{P} C$ 鋼材のピッチ が求められる。

$\mathrm{PCC}$ 鋼材の配置には, 高さとプレストレス力との関 係図から，使用する P C 鋼材の直径に対するピッチを 求める計算図を示していて便利である。

鉛直方向のプレストレスについて，基礎と壁の打継 ぎ部ではスライド方式を採用し，プレストレス導入時 に壁がスライドすることによって，打継ぎ部に大きな 応力を発生しないよう考虑されて扣り，これを分かり やすく図解している（Fig. 5.4）。導入以後はピン支持
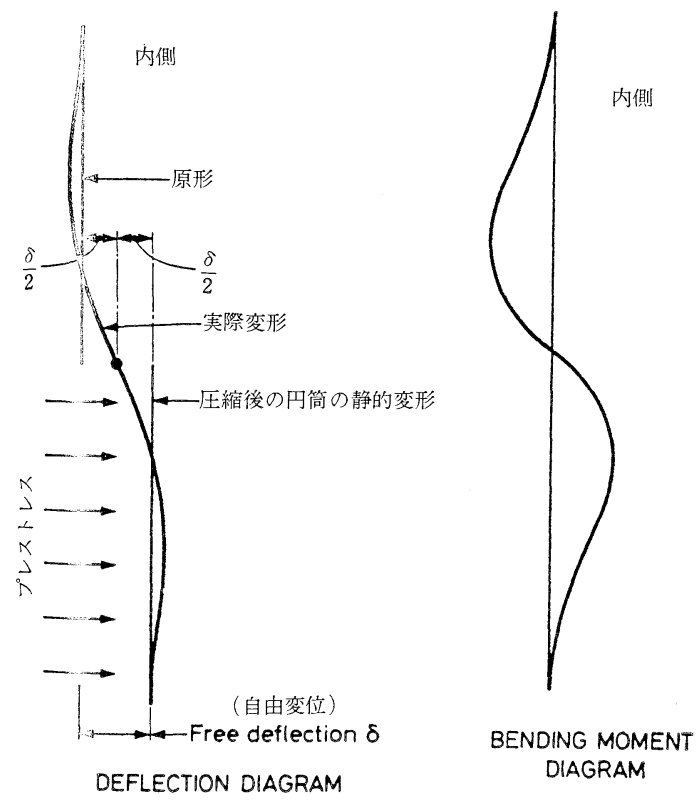

変形図

曲げモーメント図

Fig. 5.7 Effects of winding stress. (捻り応力の影響)
とし，変位を防ぎ，わずかな回転のみを許すものとな る。またプレストレスの導入による曲げ応力と同時 に, 使用時の温度こう配による曲げ応力が, 壁と基礎 の接合部の拘束によって生ずることの注意を喚起して いる。

構造解析に拈いて, 曲げモーメント及びせん断力に ついては, チモシェンコ, フリューガー, ローク，デ ン・ハルトック他の文献ををとめて Table 5.1 に示さ れている。な特，この表ではポアソン比が含まれてい るが実際にはあまり重要でないので，単に 0.2 として よいとしている。

さらに，円周方向プレストレス，液圧，プレストレ ス導入時の曲济応力，温度こう配による曲げ，鉛直方 向合成応力及び $\mathrm{P} \mathrm{C}$ 鋼材の決定について計算例を示し ている。

しかし，わが国における地震時の安全性を考慮した 水平力を計算に入れるとやや複雑なものとなるので, 上記の解にさらに横力を入れた検討が必要である。

外部タンク;

通常はイニシャルコストが低いので, 外部タンク及 び屋根ドームは炭素鋼で造られる。この章では外部夕 ンクをコンクリートで造る場合についてのみ触れられ ている。

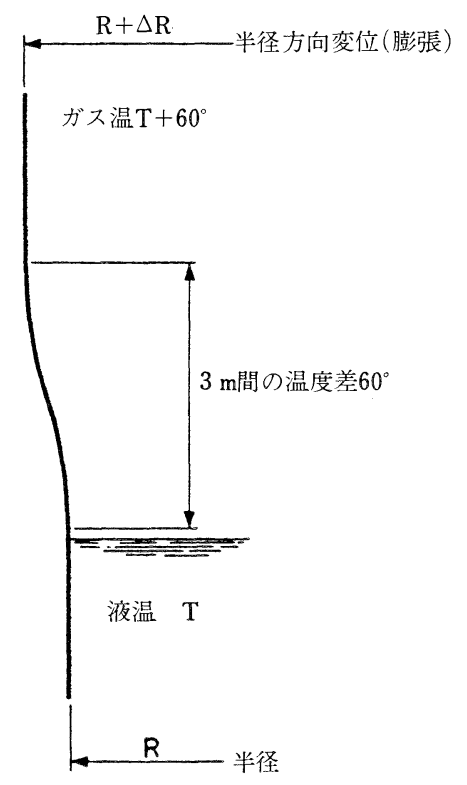

Fig. 5. 8 Bending due to thermal gradient. (温度差による曲げ変形，半径方 向膨張))

Vol. 18 No. 4 (1983) 


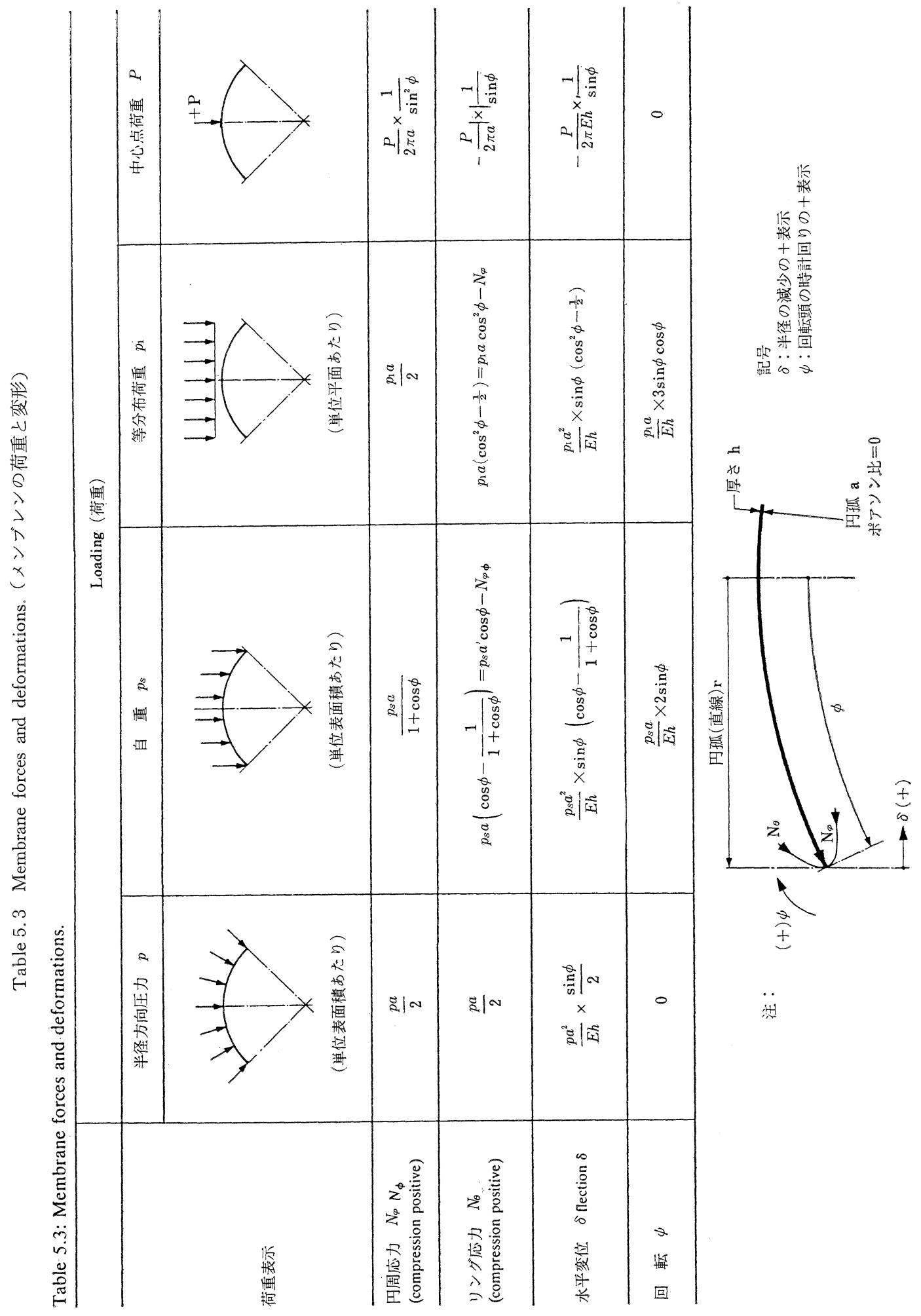

低温工学 
Table 5.4 Membrane stresses and deformations for a thin dome. (薄肉ドームの場合の メンブレンの応力と変形)

\begin{tabular}{|c|c|c|c|c|c|}
\hline & \multicolumn{3}{|c|}{ 荷 } & \multicolumn{2}{|l|}{ 重 } \\
\hline & 半径方向圧力 & 半径方向圧力 & 自 & 等分布荷重 & 中心点荷重 \\
\hline & $+1 \mathrm{kN} / \mathrm{m}^{2}$ & $-14 \mathrm{kN} / \mathrm{m}^{2}$ & $+3.6 \mathrm{kN} / \mathrm{m}^{2}$ & $+1 \mathrm{kN} / \mathrm{m}^{2}$ & $+50 \mathrm{kN}$ \\
\hline 忊周 応力 $N_{\phi}(\mathrm{kN} / \mathrm{m})$ & +23.96 & -335.39 & +91.44 & +23.96 & 0.75 \\
\hline リング応力 $N_{\theta}(\mathrm{kN} / \mathrm{m})$ & +23.96 & -335.39 & +60.44 & +13.27 & -0.75 \\
\hline 水平変 位 $\delta(\mathrm{m})$ & $\frac{+3586}{E}$ & $\frac{-50204}{E}$ & $\frac{+9067}{E}$ & $\frac{+1198}{E}$ & $\frac{+113}{E}$ \\
\hline \multirow[t]{2}{*}{ 廻 転 $\phi(\mathrm{rad})$} & 0 & 0 & $\frac{+1080}{E}$ & $\frac{+397}{E}$ & 0 \\
\hline & \multicolumn{2}{|c|}{ 最大圧縮力 } & \multicolumn{3}{|c|}{ 最大引張力 } \\
\hline$N_{\phi}(\mathrm{kN} / \mathrm{m})$ & \multicolumn{2}{|c|}{+130.11} & \multicolumn{3}{|c|}{-243.20} \\
\hline$N_{0}(\mathrm{kN} / \mathrm{m})$ & \multicolumn{2}{|c|}{+96.72} & \multicolumn{3}{|c|}{-275.70} \\
\hline
\end{tabular}

Table 5.5 Membrane forces and deformations for a thick done.（厚肉ドームの場合の メンブレンの応力と変形)

\begin{tabular}{|c|c|c|c|c|c|}
\hline & \multicolumn{3}{|c|}{ 荷 } & \multicolumn{2}{|l|}{ 重 } \\
\hline & 半径方向圧力 & 半径方向圧力 & 自 & 等分布荷重 & 中心点荷重 \\
\hline & $+1 \mathrm{kN} / \mathrm{m}^{2}$ & $-14 \mathrm{kN} / \mathrm{m}^{2}$ & $\left|\begin{array}{c}+7.2 \mathrm{kN} / \mathrm{m}^{2} \\
\text { (on inner dome) }\end{array}\right|$ & & $+50 \mathrm{kN}$ \\
\hline$N_{\phi}(\mathrm{kN} / \mathrm{m})$ & +23.96 & -335.39 & +182.88 & +23.96 & +0.75 \\
\hline$N_{\theta}(\mathrm{kN} / \mathrm{m})$ & +23.96 & -335.39 & +120.88 & +13.27 & -0.75 \\
\hline$\delta$ & $+1793 / E$ & $-25102 / E$ & $+9067 / E$ & $+599 / E$ & $+57 / E$ \\
\hline$\psi$ & 0 & 0 & $+1080 / E$ & $+199 / E$ & 0 \\
\hline
\end{tabular}

最大压縮力： $221.55 \mathrm{kN} / \mathrm{m}$. 最大引張力： $211.26 \mathrm{kN} / \mathrm{m}$.

屋根ドームは浅い円弧形シェルで，内圧に耐觉から 耐火性を持たせるため，鉄板の上にコンクリートでラ イニングしたものが用いられる。スパンに対する高さ の比は $6 \sim 10$ 程度である。計算方法は多くの参考書に あるので，ここでは単に引用したとしている。

力と変形の公式は, 半径方向圧力, 自重, 積載荷重 及び中央集中荷重とこれに対応する軸力，水平方向変 位及び回転について表示されている注か，薄肉及び厚 肉ドームの計算例が表示されている。

その他壁，基礎についても一応の計算が示されてい る。ただし前にも述べたように耐震的な計算がなされ ていないので，わが国で用いる場合にはこれに地震時

Vol. 18 No. 4 (1983)
の解析を加える必要がある。

防護壁について，災害時に液が動き出した時の速 度， $\sqrt{2 g h}$ から壁に掛かる圧力の計算が示されてい る。また，火苂時の温度の推定が図示されていて参考 となる (Fig. 5.22)。

透気性について；液体が多孔性物質を通過する場合 は，表面積，透過する樑さまたは壁厚，液体の圧力及 び粘度，並びに抵抗によって決まり，ダルシィの法則 に従うとしている。即ち通過割合 $Q\left(\mathrm{~cm}^{3} / \mathrm{s}\right)$ は $k A p / \nu l$ で表わされる。ここに $k$ は物質の透過係数 $\left(\mathrm{cm}^{2}\right), A$

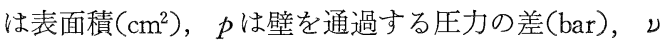
は粘度（センチポアズ）及び $l$ は壁厚を示す。この抵 


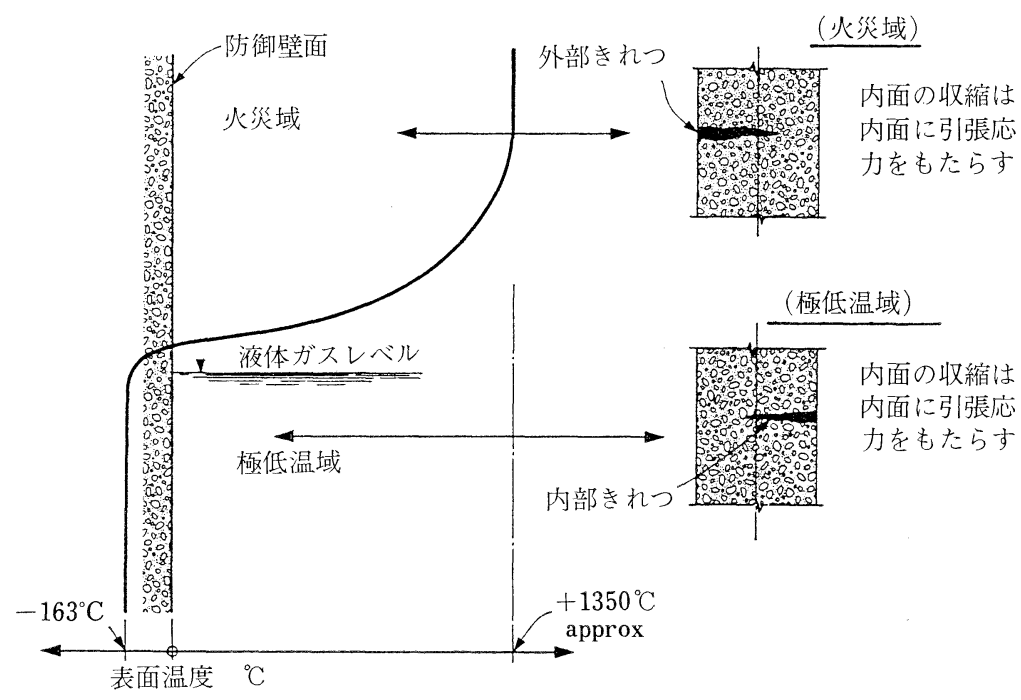

Fig. 5.22 Effects of fire on guard wall.（防護壁に及洔す火焰の影響）

抗を増すためには、コンクリートを湿潤にしておくの がよいとしている。

\section{6 章}

その他の適用について簡単な箇条書きで述べられて いる添か，コンクリート船について“コントランスタ 一” 及び“ダイタム”の断面が載せられている（Fig. 6.2)。

付録では，主として使用する力，粘度，温度，熱， 仕事量, エネルギー等の単位の換算表, 低温工学に掠 いて特に使用する潜熱，比熱，熱伝導率の単位の換算 表，天然ガスの組成例，液状及び気体としての容積の 換算表が最初にある。液化ガスの物理的性算, 液化臨 界温度と圧力, ガス体及び保冷材の性質, 蒸発量並び に保冷材の性質等が，設計資料として載せられていて 便利である (末尾 Charts 6 14参照)。

\section{あとがき}

以上本書の概要を紹介した結果を以下にまとめる。 液化ガス，特に LNG 貯蔵タンクにプレストレス ト・コンクリートを採用する場合に有用であり，かな り広範に触れられている参考書として他に類がない。 内容的に不足な点はあるが，これは各專門分野にとっ て個々に必要な文献を調査すべきで，各方面の掛わり 合いを知るためには本書の通読によって他の専門分野 の範囲まで知るには手頃な手引書である。な物，構造 設計面では耐震的配慮がなされていないので，例光ぱ 日本建築学会で審議中の「容器構造設計指針(案)」が 参考となろう。また本書では主として地上タンクにつ いて述べられて扮り, 地下タンクについては触れられ ていないので，この辺については日本瓦斯協会の「L N G 地下式貯槽指針」を閲読することが望ましい。し かし LNG 全般についての理解を深め, 多角的に経済 性，安全性を検討するには，本書が十分役立つ技術叢 書として推奖されると考光る。 

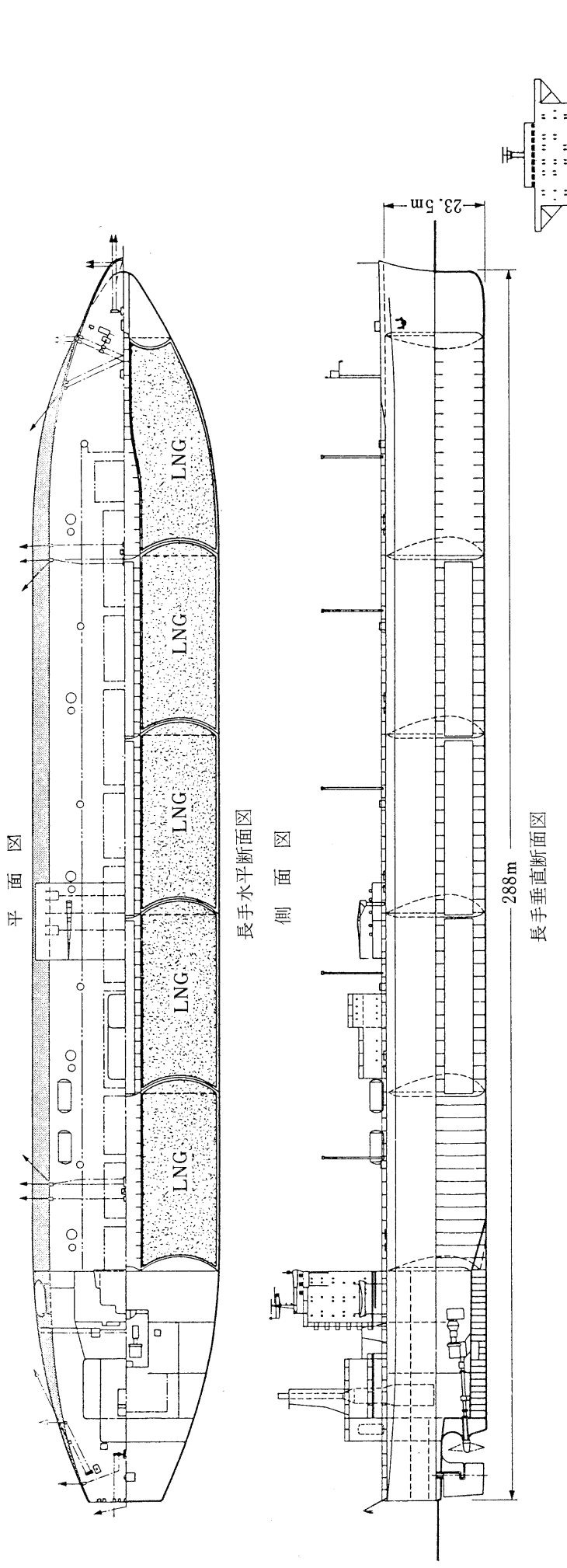

Vol. 18 No. 4 (1983) 
Chart 6: Conversion factors for specific heat. (比熱換算表)

\begin{tabular}{l|c|c|c|c}
\hline & $\stackrel{1 \mathrm{~J} / \mathrm{kg}{ }^{\circ} \mathrm{C}}{=}$ & $\stackrel{1 \mathrm{~kJ} / \mathrm{kg}{ }^{\circ} \mathrm{C}}{=}$ & $1 \mathrm{cal} / \mathrm{g}{ }^{\circ} \mathrm{C}$ & $1 \mathrm{Btu} / \mathrm{lb}{ }^{\circ} \mathrm{F}$ \\
\hline $\mathrm{J} / \mathrm{kg}{ }^{\circ} \mathrm{C}$ & 1 & $1 \times 10^{3}$ & $4.19 \times 10^{3}$ & $4.19 \times 10^{3}$ \\
$\mathrm{~kJ} / \mathrm{kg}{ }^{\circ} \mathrm{C}$ & $1 \times 10^{-3}$ & 1 & 4.19 & 4.19 \\
$\mathrm{cal} / \mathrm{g}{ }^{\circ} \mathrm{C}$ & $239 \times 10^{-6}$ & 0.239 & 1 & 1 \\
$\mathrm{Btu} / \mathrm{lb}{ }^{\circ} \mathrm{F}$ & $239 \times 10^{-6}$ & 0.239 & 1 & 1 \\
\hline
\end{tabular}

Chart 7: Conversion factors for thermal conductivity. (熱伝導率換算表)

\begin{tabular}{|c|c|c|c|c|c|}
\hline & $\begin{array}{c}1 \mathrm{~W} / \mathrm{m}{ }^{\circ} \mathrm{C} \\
\left(\text { or } 1 \mathrm{~J} / \mathrm{m}{ }^{\circ} \mathrm{C} \text { ) }\right. \\
=\end{array}$ & $\begin{array}{c}1 \mathrm{~W} / \mathrm{mm}^{\circ}{ }^{\circ} \mathrm{C} \\
\left(\text { or } \mathrm{J} / \mathrm{mm}^{\circ} \mathrm{C} \text { ) }\right. \\
=\end{array}$ & $\begin{array}{c}1 \mathrm{kcal} / \mathrm{m} \mathrm{h}^{\circ} \mathrm{C} \\
\text { (or } 1 \mathrm{cal} / \mathrm{mm} \mathrm{h}^{\circ} \mathrm{C} \text { ) } \\
=\end{array}$ & $1 \mathrm{Btu} \stackrel{\mathrm{ft} / \mathrm{ft}^{2} \mathrm{~h}^{\circ} \mathrm{F}}{=}$ & $\stackrel{\mathrm{Btu} \text { in } / \mathrm{ft}^{2} \mathrm{~h}^{\circ} \mathrm{F}}{=}$ \\
\hline $\begin{array}{l}\mathrm{W} / \mathrm{m}{ }^{\circ} \mathrm{C} \\
\text { (or } \mathrm{J} / \mathrm{m}{ }^{\circ} \mathrm{C} \mathrm{s} \text { ) }\end{array}$ & 1 & $1 \times 10^{-3}$ & 1.163 & 1.731 & 0.1442 \\
\hline $\begin{array}{l}\mathrm{W} / \mathrm{mm}^{\circ}{ }^{\circ} \mathrm{C} \\
\text { (or } \mathrm{J} / \mathrm{mm}^{\circ} \mathrm{C} \mathrm{s} \text { ) }\end{array}$ & $1 \times 10^{-3}$ & 1 & $1.163 \times 10^{-3}$ & $1.731 \times 10^{-3}$ & $144 \times 10^{-6}$ \\
\hline $\begin{array}{l}\mathrm{kcal} / \mathrm{m} \mathrm{h}^{\circ} \mathrm{C} \\
\left(\text { or } \mathrm{cal} / \mathrm{mm} \mathrm{h}^{\circ} \mathrm{C}\right)\end{array}$ & 0.8598 & 859.8 & 1 & 1. 488 & 0.1240 \\
\hline Btu $\mathrm{ft} / \mathrm{ft}^{2} \mathrm{~h}{ }^{\circ} \mathrm{F}$ & 0.5778 & 577.8 & 0.6720 & 1 & 0.0833 \\
\hline Btu of $/ \mathrm{ft}^{2} \mathrm{~h}{ }^{\circ} \mathrm{F}$ & 6.933 & $6.933 \times 10^{3}$ & 8.064 & 12 & 1 \\
\hline
\end{tabular}

Chart 8: Some compositions of natural gas. (天然ガスの組成例)

\begin{tabular}{l|c|c|c|c|c|c|c|c}
\hline \multirow{2}{*}{ Constituents } & \multicolumn{7}{|c|}{ Source } & $\begin{array}{c}\text { Typical } \\
\text { design } \\
\text { range }\end{array}$ \\
\cline { 2 - 9 } & North Sea & Algeria & Libya & USA & Alaska & Sakhalien & Lacq & \\
\hline Methane: $\mathrm{CH}_{4}$ & 94 & $84-88$ & $67-70$ & 89 & 95.6 & 97.4 & 98.8 & $83-99$ \\
Ethane: $\mathrm{C}_{2} \mathrm{H}_{6}$ & 4 & $8-11$ & $15-20$ & 6 & 2.3 & 1.5 & 0.9 & $1-13$ \\
Propane: $\mathrm{C}_{3} \mathrm{H}_{8}$ & 1 & $2.4-3$ & $8.7-10$ & 1 & 1.3 & 0.1 & 0.1 & $0.1-3$ \\
Butanes: $\mathrm{C}_{4} \mathrm{H}_{10}$ & 1 & $0.8-1.1$ & $3-3.5$ & 0 & 0.1 & 0 & 0 & $0.2-1$ \\
Pentanes: $\mathrm{C}_{5} \mathrm{H}_{12}$ & 1 & $0.1-0.7$ & $0.5-0.7$ & 1 & 0 & 0 & 0 & $0-1$ \\
Nitrogen: $\mathrm{N}_{2}$ & 1 & $0.3-0.7$ & $0-0.9$ & 3 & 0.6 & 1.0 & 0.2 & $0-1$ \\
\hline
\end{tabular}

注 1） 単位は容積\%

2) 組成は前処理後の結果を示す

3）值は公表されている文献淿ある分析值である

4）どの出所のガスも時として組成の大きなばらつきを示す

5）重いガスの成分が高いものは反転（roll over）傾向が増す 


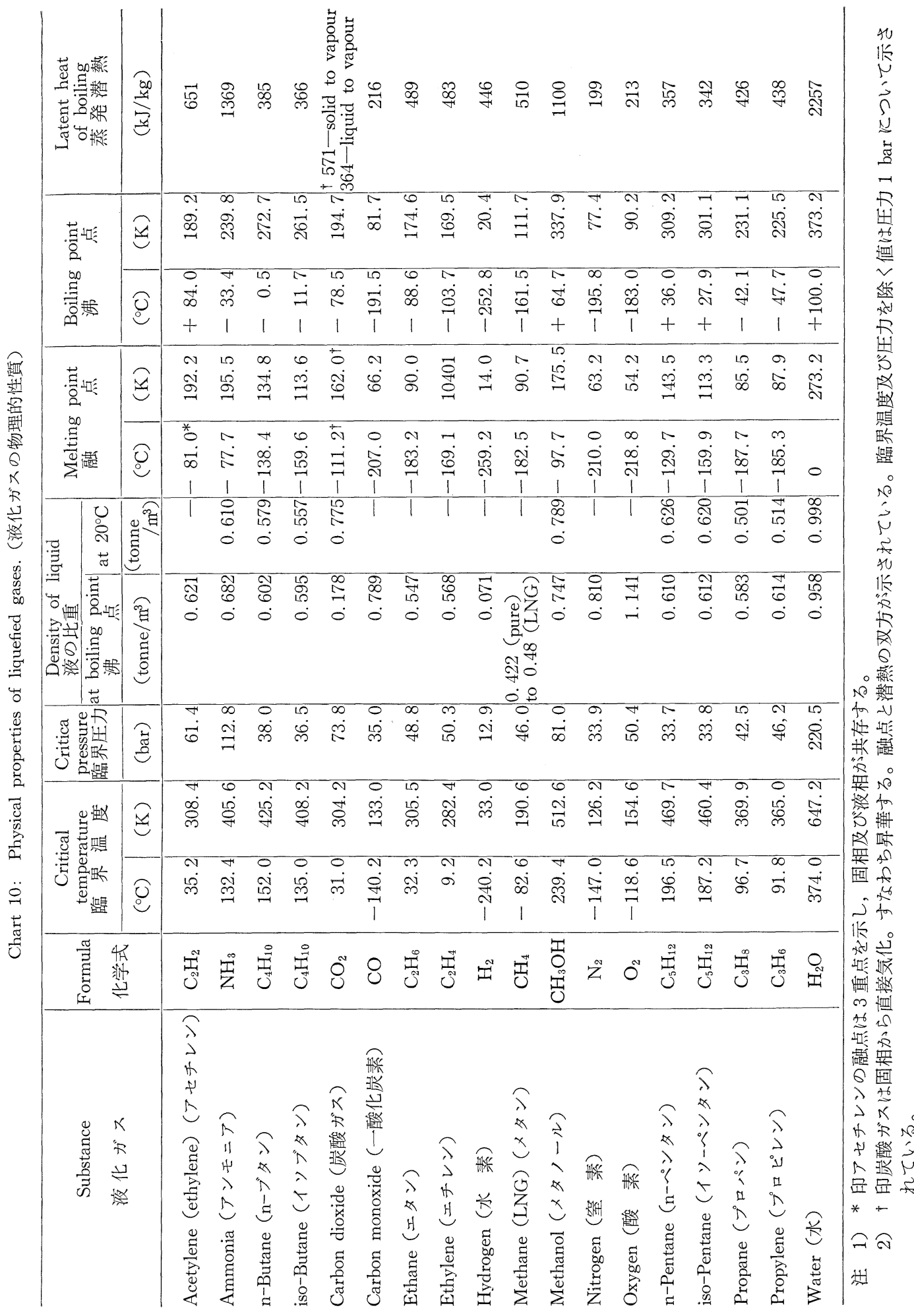

Vol. 18 No. 4 (1983) 
Chart 11: Physical properties of gases and liquefied gases. (ガス及び液化ガスの物理的性質)

\begin{tabular}{|c|c|c|c|c|c|c|c|}
\hline & \multirow{2}{*}{$\begin{array}{c}\text { 比 熱 } \\
\text { (定圧下) } \\
\left(\mathrm{kJ} / \mathrm{kg}{ }^{\circ} \mathrm{C}\right)\end{array}$} & \multirow{2}{*}{$\begin{array}{l}\text { 発 熱量 } \\
\left(\mathrm{MJ} / \mathrm{m}^{3}\right)\end{array}$} & \multicolumn{2}{|c|}{ 相対蒸気 密 度† } & \multirow[b]{2}{*}{ 容積減小率* } & \multicolumn{2}{|l|}{ 粘 } \\
\hline & & & 沸点 & $\begin{array}{ll}\text { 常 温 } \\
\text { 常 王 }\end{array}$ & & $\begin{array}{l}\text { 常 } \\
\text { 常 } \\
\left(\mathrm{Ns} / \mathrm{m}^{2}\right)^{\text {温 }}\end{array}$ & $\begin{array}{l}\text { 沸 点 } \\
\left(\mathrm{Ns} / \mathrm{m}^{2}\right)\end{array}$ \\
\hline Acetylene (ethyne) & 1.66 & 55.0 & 1.364 & 0.899 & $1 / 560$ & $9.35 \times 10^{-6}$ & $\begin{array}{l}\text { approx } \\
140 \times 10^{-6}\end{array}$ \\
\hline Ammonia & 2.08 & 16.2 & 0.704 & 0.588 & $1 / 950$ & $9.18 \times 10^{-6}$ & $174 \times 10^{-6}$ \\
\hline n-Butane & 1.63 & 121.8 & 2. 112 & 2.006 & $1 / 250$ & $\begin{array}{c}\text { approx } \\
8.5^{-6} \times 10^{-6}\end{array}$ & $241 \times 10^{-6}$ \\
\hline iso-Butane & 1.62 & 121.4 & 2.203 & 2.006 & $1 / 240$ & $\underset{8.5}{\text { approx }} \times 10^{-6}$ & $239 \times 10^{-6}$ \\
\hline Carbon dioxide & 0.833 & - & 2.240 & 1.519 & $1 / 630$ & $14.0 \times 10^{-6}$ & $138 \times 10^{-6}$ \\
\hline Carbon monoxide & 1.04 & 12.0 & 3.400 & 0.967 & $1 / 670$ & $16.6 \times 10^{-6}$ & $171 \times 10^{-6}$ \\
\hline Ethane & 1.71 & 66.4 & 1.707 & 1.038 & $1 / 430$ & $9.1 \times 10^{-6}$ & $162 \times 10^{-6}$ \\
\hline Ethylene & 1.51 & 59.7 & 1.640 & 0.968 & $1 / 480$ & $9.70 \times 10^{-6}$ & $125 \times 10^{-6}$ \\
\hline Hydrygen & 14.3 & 12.1 & 0.985 & 0.070 & $1 / 830$ & $8.35 \times 10^{-6}$ & $12.3 \times 10^{-6}$ \\
\hline Methane (LNG) & 2.21 & 37.7 & 1. 424 & 0.554 & $\begin{array}{l}1 / 620 \text { (pure) } \\
1 / 630 \text { (LNG) }\end{array}$ & $10.3 \times 10^{-6}$ & $142 \times 10^{-6}$ \\
\hline Methanol & 1.35 & $(32.3)$ & 0.940 & (1.106) & - & - & $*_{6} 600 \times 10^{-6}$ \\
\hline Nitrogen & 1.04 & - & 3.588 & 0.967 & $1 / 690$ & $16.7 \times 10^{-6}$ & $141 \times 10^{-6}$ \\
\hline Oxygen & 0.916 & - & 3.515 & 1.104 & $1 / 800$ & 19. $2 \times 10^{-6}$ & $166 \times 10^{-6}$ \\
\hline $\mathrm{n}$-Pentane & 1.62 & 149.7 & 2.312 & $(2.490)$ & 一 & - & $* 205 \times 10^{-6}$ \\
\hline iso-Pentane & 1.60 & 149.4 & 2.375 & $(2.490)$ & - & - & $* 216 \times 10^{-6}$ \\
\hline Propane & 1.62 & 93.9 & 1.891 & 1.522 & $1 / 310$ & $8.0 \times 10^{-6}$ & $216 \times 10^{-6}$ \\
\hline Propylene & 1. 48 & 87.1 & 1.849 & 1. 452 & $1 / 350$ & $8.3 \times 10^{-6}$ & $\begin{array}{c}\text { approx } \\
200 \times 10^{-6}\end{array}$ \\
\hline Water & 1.86 & - & 0.479 & $(0.652)$ & - & - & $* 1000 \times 10^{-6}$ \\
\hline
\end{tabular}

注 1) ことわりのない限り，常温・常圧 (STP) での乾燥ガスとしての值を示す； STP $15^{\circ} \mathrm{C}, 1013.25 \mathrm{mbar}$

2) * 印容積減小率は, 常温常圧下のガスの密度に対する沸点の液の容積比率を示すメタノール, ペン タン，及び水は常温，常圧下の值を示す。

これらの液体の粘度は常温常圧下の值で示されている。

3) †印相対蒸気密度は常温常圧下の空気の密度に対する比で示されている。 実際の比重は表の值に1, 293を乗じて得られる。 
Chart 12: Relationship between liquefaction temperature and pressure of cryogenic liquids. (極低温下の液化温度と圧力の関係)

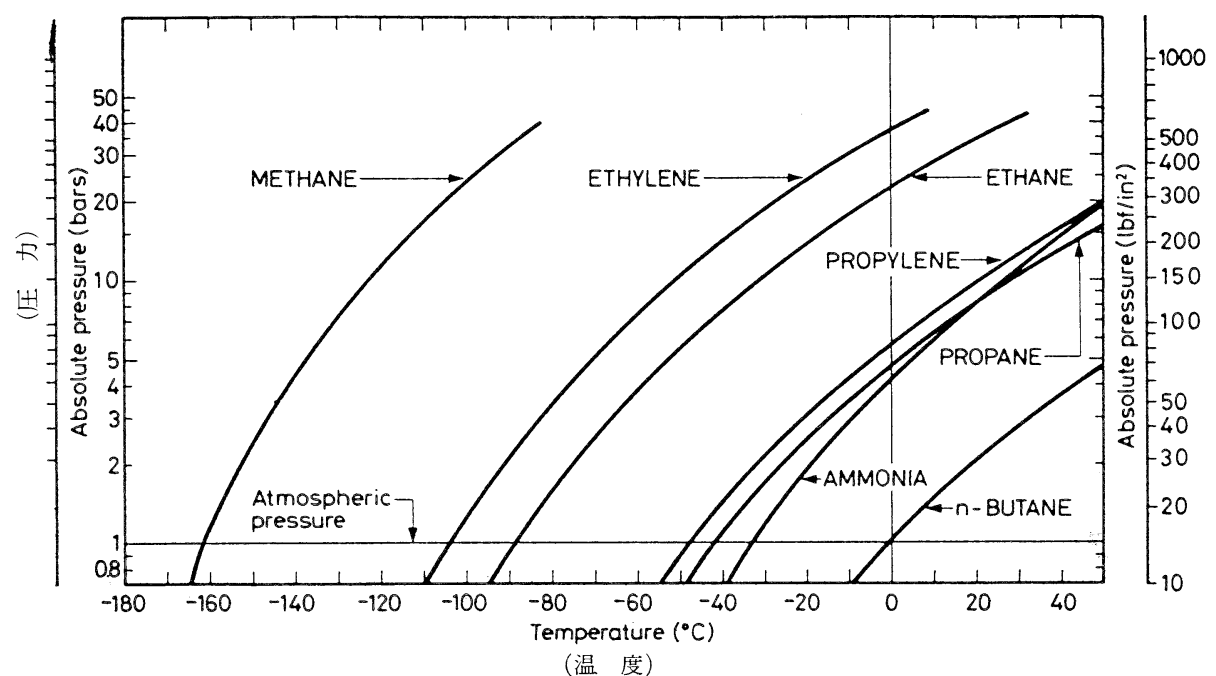

Chart 13: Properties of insulants. (保冷材 (断熱材) の性質)

\begin{tabular}{|c|c|c|c|c|c|c|c|}
\hline Properties & \multirow{2}{*}{$\frac{\text { 発泡ガラス }}{144}$} & \multirow{2}{*}{$\frac{\begin{array}{l}\text { パーラ } \\
\text { イト粒 }\end{array}}{30-50}$} & \multirow{2}{*}{\begin{tabular}{l} 
パーライト \\
コンクリー \\
ト \\
\multicolumn{1}{c}{720}
\end{tabular}} & \multicolumn{2}{|c|}{ 発泡ポリスチレン } & \multicolumn{2}{|c|}{$\begin{array}{lll}\text { 発泡 ポ } & \text { タ } \\
\text { ウ } & \text { タ }\end{array}$} \\
\hline 密 度 $\left(\mathrm{kg} / \mathrm{m}^{3}\right)$ & & & & 16 & 28 & 30 & 300 \\
\hline 平均熱容量 & 0.04 & 0.029 & 0.092 & 0.04 & 0.04 & 0.025 & 0.05 \\
\hline 圧 縮 強 度 & 0.69 & - & 1. 20 & 0.08 & 0.25 & 0.20 & 2. 30 \\
\hline 引 張 強 度 & 0.45 & - & 0.10 & 0.22 & 0.24 & 0.35 & 2. 40 \\
\hline$\left(\mathrm{N} / \mathrm{mm}^{2}\right)$ & 0.52 & - & 0.21 & 0.17 & 0.31 & 0.38 & 3. 40 \\
\hline 熱 膨 張 率 & $8.3 \times 10^{-6}$ & - & - & $72 \times 10^{-6}$ & $72 \times 10^{-6}$ & - & - \\
\hline
\end{tabular}

注；1）值は代表的なるのを示す。他のデータはメーカーの資料で得られる。

2) コンクリートの熱伝導率は約 $3.5 \mathrm{~W} / \mathrm{m}^{\circ} \mathrm{C}\left(=3.0 \mathrm{kcal} / \mathrm{m} \mathrm{h}{ }^{\circ} \mathrm{C}\right)$ 。

3）氷の熱伝導率は約 $6 \mathrm{~W} / \mathrm{m}{ }^{\circ} \mathrm{C}\left(=5.2 \mathrm{kcal} / \mathrm{m} \mathrm{h}{ }^{\circ} \mathrm{C}\right)$ 。

4) $\mathrm{W} / \mathrm{m}{ }^{\circ} \mathrm{C}$ を $\mathrm{kJ} / \mathrm{m}{ }^{\circ} \mathrm{Ch}$ に換算するには表の值を 3.6 倍する。 
蒸発量 (LNG)

\begin{tabular}{l|c}
\hline $1 \mathrm{~m}^{3}$ の乾燥した土で & $1 \mathrm{~m}^{3}$ \\
$1 \mathrm{~m}^{3}$ の湿った土で & $3 \mathrm{~m}^{3}$ \\
$1 \mathrm{~m}^{3}$ の水で & $4 \mathrm{~m}^{3}$ \\
$1 \mathrm{~m}^{3}$ の空気常 (温常圧) & $100 \times 10^{-6} \mathrm{~m}^{3}$ \\
\hline
\end{tabular}

○土またはコンクリートの上に洩れた LNG は，最初 に約 $2.5 \mathrm{~m}^{3} / \mathrm{min} / \mathrm{m}^{2}$ (表面) の割合で蒸発し，安定 状態で $0.25 \mathrm{~m}^{3}$ に減少する。

OLNG の燃焼割合は安定状態で深さ $5 \sim 15 \mathrm{~mm} /$ minである。

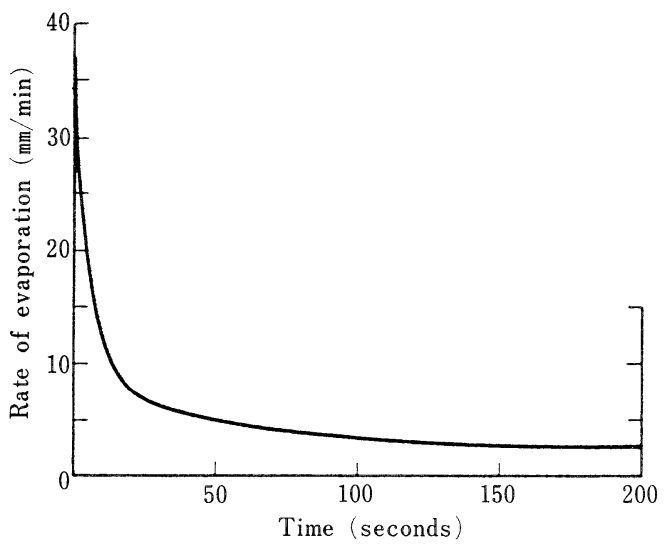

个経過時間之蒸発量

Properties of gases（ガスの性質）

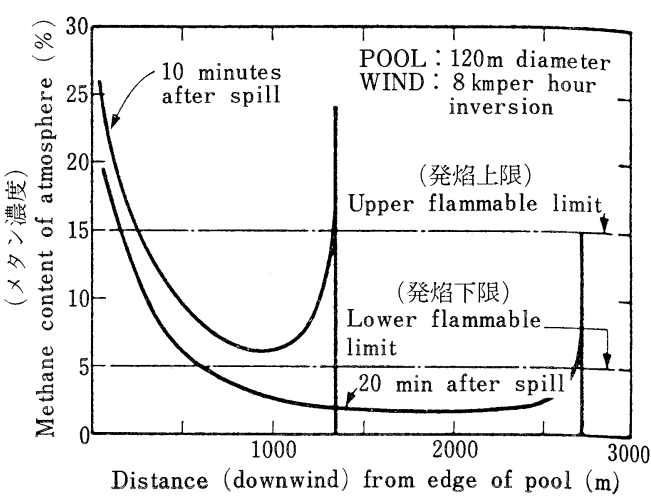

个溜りの端からの距離と風下のメタンガス濃度

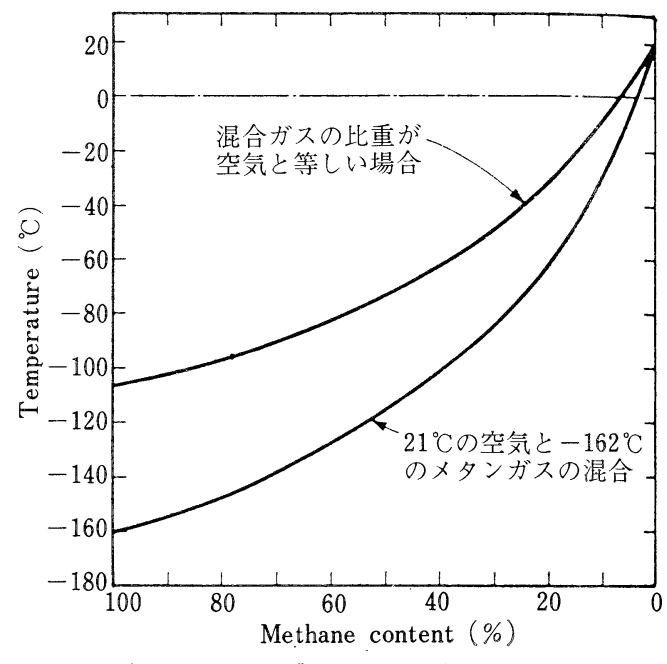

^メタンガス濃度と温度との関係

\begin{tabular}{|c|c|c|c|c|c|c|}
\hline \multirow[t]{2}{*}{$\begin{array}{l}\text { Substance } \\
\left(\begin{array}{l}\text { (ガ }\end{array}\right.\end{array}$} & \multirow{2}{*}{$\begin{array}{l}\text { Relative } \\
\text { vapour } \\
\text { density* } \\
\text { 比重比 }\end{array}$} & \multicolumn{2}{|c|}{$\begin{array}{l}\text { Explosive limits } \\
\text { ( \% by volume) } \\
\text { 爆発限界 (\% vol) }\end{array}$} & \multirow{2}{*}{$\begin{array}{l}\text { Flash } \\
\text { point } \\
\left.\text { ( }{ }^{\circ} \mathrm{C}\right) \\
\text { 引 火 点 }\end{array}$} & \multirow{2}{*}{$\begin{array}{c}\text { Ignition } \\
\text { temperature } \\
\left.\text { ( }{ }^{\circ} \mathrm{C}\right) \\
\text { 燃焼温度 }\end{array}$} & \multirow{2}{*}{\begin{tabular}{|} 
Maximum \\
allowable \\
concentration \\
(parts per \\
million) \\
最大濃度 $\left(1 / 10^{6}\right)$
\end{tabular}} \\
\hline & & Lower & Upper & & & \\
\hline Acetaldehyde & 1.52 & 4 & 55 & -38 & 185 & 200 \\
\hline Ammonia & 0.588 & 14 & 28 & Indefinite & 652 & 50 \\
\hline Butadiene & 1.88 & 2 & 11.5 & -60 & 450 & 1000 \\
\hline Butane & 2.01 & 1.8 & 8.5 & -60 & 406 & Not applicable \\
\hline Ethylene & 0.968 & 2.7 & 28.5 & Very low & 450 & 5500 \\
\hline Ethylene oxide & 1.52 & 3 & 100 & -57 & 429 & 50 \\
\hline Methane & 0.554 & 5.3 & 14 & Very low & 595 & Not applicable \\
\hline Methanol & 1. 106 & 6 & 36.5 & +10 & 470 & 1000 \\
\hline Propane & 1.522 & 2.1 & 9.5 & -105 & 470 & Not applicable \\
\hline Vinyl chloride & 2.20 & 4 & 22 & -78 & 472 & 500 \\
\hline
\end{tabular}

注；*関係比重は常温常圧の空気に対するガスの比重比率，真比重は上の值を1.293倍する。 